Zucchetto, M. F., N. S. Da Silveira, V. M. Prasniewski, T. Arnhold, T. Sobral-Souza, and J. B. de Pinho. 2021. Effects of future climate change on the geographical distribution of a bird endemic to South American floodplains. Avian Conservation and Ecology 16(2):29. https://doi.org/10.5751/ ACE-01893-160229

Copyright (C 2021 by the author(s). Published here under license by the Resilience Alliance.

Research Paper

\title{
Effects of future climate change on the geographical distribution of a bird endemic to South American floodplains
}

\author{
Mayara F. Zucchetto ${ }^{1}$ (D) , Natalia S. Da Silveira ${ }^{2}$, Victor M. Prasniewski ${ }^{1}$, Tatiane Arnhold ${ }^{1}$, Thadeu Sobral-Souza ${ }^{3}$ and João B. \\ de Pinho ${ }^{1}$ \\ ${ }^{1}$ Postgraduate Program in Ecology and Biodiversity Conservation, Department of Botany and Ecology, Institute of Biosciences, \\ Federal University of Mato Grosso (UFMT) - Cuiabá, ${ }^{2}$ Department of Biodiversity, Institute of Biosciences, São Paulo State \\ University (UNESP), ${ }^{3}$ Macroecology and Biodiversity Conservation Lab, Department of Botany and Ecology, Institute of \\ Bioscience, Federal University of Mato Grosso (UFMT) - Cuiabá
}

\begin{abstract}
Future climate change poses an immediate threat to biodiversity. Species are shifting their geographic distribution in direct response to climate change. Species around the globe are expected to redistribute poleward and/or to high elevations. However, in the Neotropical region, the effects of climate change on species distribution are still unclear. Here, we aimed to infer the current and future geographical distribution of an insectivorous bird species endemic to South American floodplains, the Mato Grosso Antbird (Cercomacra melanaria). We also estimated shifts in the variables of elevation, longitude, latitude, and slope based on forecasting. Current and future distribution in different climate scenarios were predicted using ecological niche modeling (ENM). A non-parametric Kruskall-Wallis test followed by Dunn's post hoc test were carried out to determine if dependent variables (elevation, slope, latitude, and longitude) differed between climate scenarios. Our findings suggest that future climate change will have negative effects (range contraction) on the distribution of the Mato Grosso Antbird. The decrease in the species' geographical range will cause it to shift to higher elevations, latitudes, longitudes, and slopes. The species should tend to disperse toward more suitable areas located in highlands close to wetlands, such as the headwaters of the Upper Paraguay River Basin (UPB), and toward the Andean highlands. However, this species inhabits strictly forested environments covering a small home range and its mobility capacity is limited. It is possible that the species will not be able to achieve future geographical redistribution, thus increasing its risk of extinction.
\end{abstract}

\section{Effets des futurs changements climatiques sur la répartition géographique d'un oiseau endémique des plaines inondables d'Amérique du Sud}

RÉSUMÉ. Les futurs changements climatiques constituent une menace immédiate pour la biodiversité. Les espèces modifient leur répartition géographique en réaction directe aux changements climatiques. On s'attend à ce que les espèces du monde entier se redistribuent vers les pôles ou les hautes altitudes. Cependant, dans la région Néotropicale, les effets des changements climatiques sur la répartition des espèces ne sont toujours pas clairs. Dans le présent article, nous avons tenté de déduire la répartition géographique actuelle et future d'une espèce d'oiseau insectivore endémique des plaines inondables d'Amérique du Sud, le Grisin du Mato Grosso (Cercomacra melanaria). Nous avons également calculé les changements sur le plan des variables d'altitude, de longitude, de latitude et de pente en fonction des prévisions. La répartition actuelle et future selon différents scénarios climatiques a été prédite en utilisant la modélisation de niche écologique (MNÉ). Nous avons réalisé un test non paramétrique de Kruskall-Wallis, puis un test post hoc de Dunn, pour déterminer si les variables dépendantes (altitude, pente, latitude et longitude) différaient entre les scénarios climatiques. Nos résultats indiquent que les futurs changements climatiques auront des effets négatifs (contraction de l'aire) sur la répartition du Grisin du Mato Grosso. La contraction de l'aire de l'espèce se traduira par des déplacements vers des altitudes, des latitudes, des longitudes et des pentes plus élevées. Nous nous attendons à ce que l'espèce ait tendance à se disperser vers des zones plus propices situées dans les hautes terres près de milieux humides, comme les sources du bassin supérieur du fleuve Paraguay (BSP), et vers les hautes terres andines. Toutefois, cette espèce fréquente des environnements strictement forestiers, a un petit domaine vital et une capacité limitée de se déplacer. Il est donc possible que l'espèce ne soit pas en mesure de se redistribuer géographiquement dans le futur, augmentant du même coup son risque de disparition.

Key Words: Cercomacra melanaria; Mato Grosso Antbird; niche modeling; Pantanal; Thamnophilidae; wetland

Correspondent author: Mayara F. Zucchetto, Avenida Fernando Correa Da Costa, 2332, Bairro Jardim Petrópolis, Condominio Petropolis, Apto 5e, Cuiabá, Mato Grosso, Brazil, 78070-000, mayarazuchetto@gmail.com 


\section{INTRODUCTION}

Species are becoming extinct at alarming rates around the world (Dirzo and Raven 2003), with more severe losses occurring in the tropics (Crutzen 2006, Dirzo et al. 2014, Ceballos et al. 2015). Future climate change and natural habitat fragmentation have been identified as the main factors causing the biodiversity crisis (Pecl et al. 2017, Araújo et al. 2019). There is a consensus regarding the negative effects of climate change on biodiversity. Species tend to shift their geographical distribution in response to climate change (Berg et al. 2010). Globally, species are dispersing toward the poles (Pecl et al. 2017) in search of suitable habitats (Parmesan and Yohe 2003, Colwell et al. 2008). The impacts of the geographical redistribution of species have reached ecosystems and their functions, leading to the formation of new biological communities with species compositions that have never previously co-occurred (Pecl et al. 2017). However, the effects of climate change on species distribution in the tropics remain poorly understood.

In response to future climate change, species can be redistributed following latitudinal and altitudinal patterns in search of climatically suitable regions. Latitudinal redistribution tends to occur mainly toward the poles in response to changes in temperature and precipitation rates (Parmesan and Yohe 2003, Root et al. 2003, Chen et al. 2009, Sunday et al. 2012), whereas altitudinal redistribution toward highlands occurs because of to rising temperatures and reduction of glacier ice volume in mountain regions (Francou et al. 2003, Seimon et al. 2007). However, geographic and topographic redistribution may occur concurrently (Díaz-Almeyda et al. 2017). Highland species will suffer more with these effects because they will need to disperse to higher latitudes and/or altitudes, which will become geographically scanty on the planet (Şekercioğlu et al. 2008). Likewise, tropical species will tend to modify their distribution to highlands and/or higher latitudes (Kelly and Goulden 2008, Fei et al. 2017, Pecl et al. 2017). The latter is highly concerning when it comes to threatened species, which are typically characterized as having the smallest distribution ranges.

Altitudinal redistribution may result in two secondary patterns of distribution pertaining to slope and longitude (Santillán et al. 2020). Slope redistribution involves shifting species distribution from plains (less rugged terrain) to mountains (more rugged terrain). In regions with extreme topography (e.g., the Andean region), species redistribution may also follow a longitudinal pattern, but toward highlands (Jankowski et al. 2013, Santillán et al. 2020). In addition, mountains may act as a dispersion barrier, thereby particularly affecting species with limited dispersal ability (Graham et al. 2010). Thus, species dispersal will tend to occur in areas with gentle slopes. Thus, to understand the effect of climate change on species distribution, it is essential to test this effect on latitudinal, longitudinal, and slope redistribution simultaneously.

Some groups and/or species considered good biological indicators of climate change can be useful tools to understand the effects of species redistribution and how it is expected to occur in climate change scenarios (Wormworth and Şekercioğlu 2011, Şekercioğlu et al. 2012). To this end, such species must be known and their occurrence must be well documented (Peterson et al. 2011). Thus, estimates of distribution and tolerance to habitat characteristics should be as realistic as possible, enabling the identification of priority areas and more effective conservation strategies.

In this regard, it is significant that birds currently represent the most well-known and understood group, even in climate change research (Wormworth and Şekercioğlu 2011, Şekercioğlu et al. 2012). Bird species distributions are strongly linked to seasonal changes in temperature and precipitation, making them some of the best indicators of climate change (Şekercioğlu et al. 2012, Pearce-Higgins and Green 2014). In addition, this group has the advantage of having millions of birdwatchers engaged in citizen science everywhere, contributing to the compilation of extensive data sets (Kinzelbach 1995, Lee and Nel 2020, https://www.ebird. org, https://www.wikiaves.com.br).

According to future climate simulations, bird species tend to spend more energy on thermoregulation as temperature and seasonality increase, thus compromising survival and decreasing fitness (Walsberg 1993, Crick 2003). Indirectly, climate warming may give rise to gradual changes in the availability of food resources and suitable habitats (Şekercioğlu et al. 2012). In this context, bird species that are more sensitive to future climate change may become extinct and/or shift to apparently more suitable regions that may not have specific habitats for their occurrence and/or for the maintenance of their population (Devictor et al. 2008).

The Neotropical region is home to a high diversity of bird species, of which 1919 occur solely in Brazil (Piacentini et al. 2015). Floodplains such as the Pantanal are host to most of this diversity (582 species; Nunes 2011), providing refuge for resting, feeding, and nesting of migratory and resident birds. However, there is a knowledge gap about how climate change will affect Neotropical wetlands and the species that live in them. Therefore, we selected for this study one of the few bird species endemic to the Pantanal, the world's largest seasonal floodplain. Cercomacra melanaria (Ménétriès 1835) belong to the family Thamnophilidae, popularly known as the Mato Grosso Antbird (Fig. 1). The species is resident, strictly insectivorous, its behavior is inconspicuous, and it inhabits the dense understory of humid tropical forests along waterways (Zimmer et al. 2020). The Mato Grosso Antbird's dispersal ability is limited by its shape, which prevents it from flying long distances and, hence, from crossing non-forested areas (Pinho et al. 2006, Nóbrega et al. 2017, Sheard et al. 2020). The species' known distribution is restricted to floodplains and wetlands in the Pantanal region of Brazil and Bolivia (Zimmer et al. 2020). The endemism of the species to the Pantanal floodplain means that its conservation status may be under threat from future climate change. Therefore, forecasting changes in the distribution patterns of restricted-range species in future scenarios is relevant to conservation efforts. The loss of a single species can have severe consequences that may result in the loss of ecosystem services and functions essential for entire ecosystems (Cardinale et al. 2012).

Our purpose was to determine the future potential distribution of the Mato Grosso Antbird, estimating its geographical shift in latitude, longitude, elevation, and slope. We hypothesized that the species' future potential distribution would shift toward higher altitudes and latitudes, as well as longitudinally westward into regions with higher slopes (Parmesan and Yohe 2003, Şekercioğlu et al. 2008, 2012, Pecl et al. 2017; Fig. 2). At higher longitudes and latitudes, the elevations will be higher, for example the Andes 
Fig. 1. Mato Grosso Antbird (Cercomacra melanaria) occurrence records in the Pantanal. These occurrence records were used in ecological niche modeling.
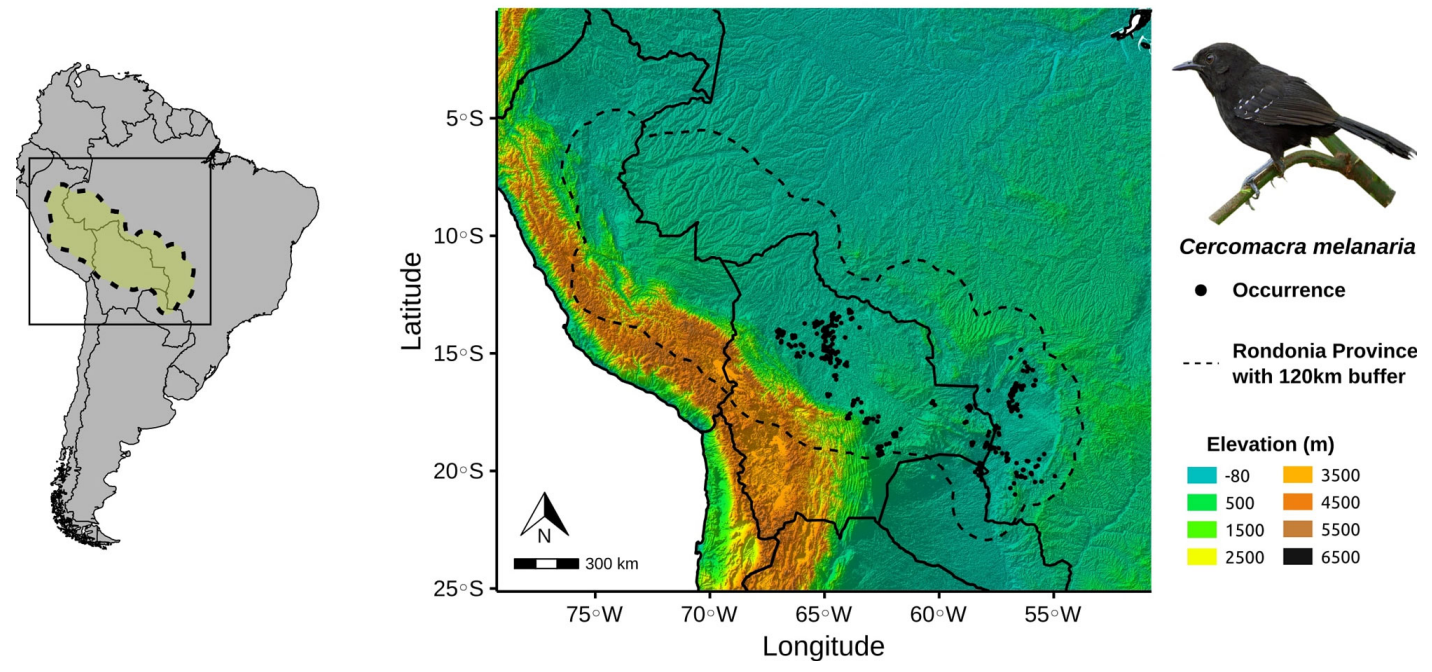

- Occurrence

Rondonia Province
with $120 \mathrm{~km}$ buffer

Elevation (m)

$-80 \quad-3500$

$500-4500$

$1500-5500$
-5500

$2500 \square 6500$

Fig. 2. Predicted habitat suitability of the variables elevation, slope, latitude, and longitude in different scenarios (present, year 2050, year 2070) and different concentrations of greenhouse gases (Representative Concentration Pathway; RCP 4.5 and RCP 8.5) for the Mato Grosso Antbird (Cercomacra melanaria). The dashed line indicates the median of the present scenario.

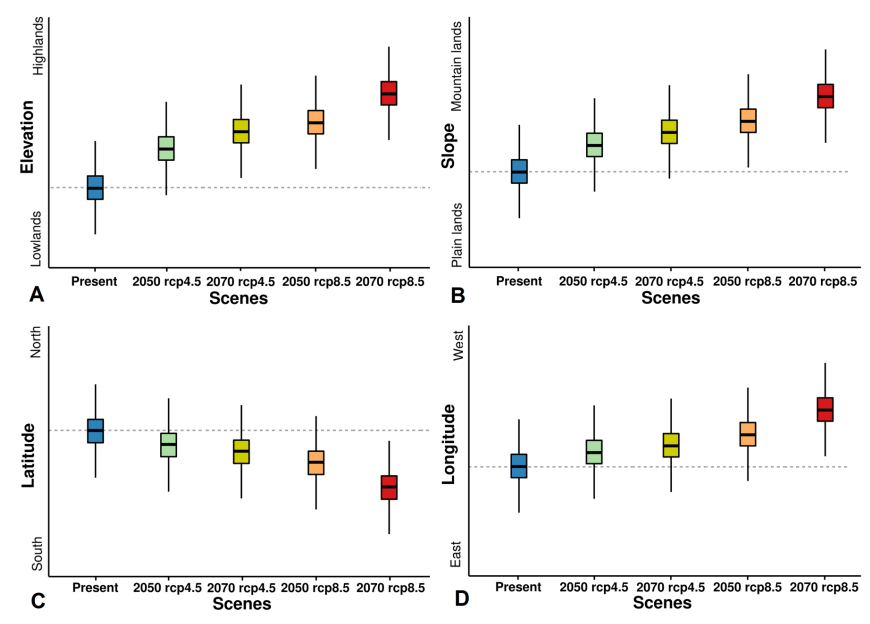

(Jankowski et al. 2013, Santilln et al. 2020), and environmental conditions should be more climatically suitable for the species in the future.

\section{METHODS}

\section{Study area}

The Mato Grosso Antbird inhabits the Brazilian and Bolivian Pantanal floodplains located in the Upper Paraguay River Basin (UPB; Fig. 1), specifically, in semi-deciduous forest areas and in the Humid Chaco in Bolivia and in the extreme north of Paraguay. Dispersion is an essential factor in the potential distribution of the species. Hence, this factor must be taken into account in the construction of distribution models, the delimitation of study areas, and the area of calibration of the Mato Grosso Antbird model. In this study, we considered the species' low dispersal ability and its preference for humid forests in low-lying floodplains, i.e., $<200 \mathrm{~m}$ (Pinho et al. 2006, Bernardon et al. 2014, Sheard et al. 2020, Zimmer et al. 2020). We assumed a delimited area covering the range of dispersion of existing populations (BirdLife International 2018, Zimmer et al. 2020), reflecting the biogeographic barriers and abiotic tolerance of the species.

The study area was defined based on the biogeographical province of Rondônia (Morrone 2014), covering all known occurrences of the species in southwestern and central Brazil, southern Peru, northwestern Bolivia, and northern Paraguay. Given that the Mato Grosso Antbird also occurs in transition zones of biogeographic provinces and considering the diffuse boundaries that delimit this biogeographical province (Morrone 2014), a buffer zone of approximately $120 \mathrm{~km}$ was added to the boundaries of the Rondônia province (Fig. 1). This background area encompasses all known species' occurrences and potential areas for historical dispersion of species, following two criteria for background selection when we applied ecological niche modeling (ENM) approaches (Barve et al. 2011).

\section{Occurrence data}

We surveyed known occurrence data using two distinct methodologies: (1) information from citizen science databases and digital databases: eBird (Sullivan et al. 2014), Global Biodiversity Information Facility (GBIF 2019), and iNaturalist (iNaturalist 2019) and (2) occurrence data provided by the Museo Nacional de História Natural, Colección Boliviana de Ornitología, Universidad Mayor de San Andrés (UMSA) and directly by researchers in the region (Dennis Camacho at the Asociación Boliviana de Ornitología, Miguel Angel Montenegro at the Museo de Historia Natural Noel Kempff Mercado, and 
Isabel Gomez and Sofia Lothesberger at the Universidad Mayor de San Andres). Occurrence records without date and site information, duplicate data, and centroid coordinates of municipalities were excluded. We compiled a total of 302 occurrence records for the 1970-2019 period, which were mapped onto a 2.5-minute grid (approximately $4.5 \times 4.5 \mathrm{~km}$ resolution at the equator; Appendix 1).

\section{Environmental variables}

To characterize background environmental space, we used all the 19 bioclimatic variables available in the WorldClim v. 1.4 database (Hijmans et al. 2005), with cell resolution size of $20.25 \mathrm{~km}^{2}$. Because these variables are derived from temperature and precipitation data, they are intercorrelated, requiring a variable selection process to decrease multicollinearity (Peterson et al. 2011). Here, we applied a factorial analysis (Revelle 2020, see Sobral-Souza et al. 2015) with maximum rotation that resulted in four selected variables: Temperature Seasonality (Bio 4), Mean Temperature of Wettest Quarter (Bio 8), Precipitation of Wettest Quarter (Bio 16), and Precipitation of Driest Quarter (Bio 17; Appendix 2). The factor analysis involved all the background points, enabling the selection of the environmental variables based on the space that was modeled.

It is important to highlight that Worldclim 1.4 uses the 1950-2000 time series to encompass temporal variations in climatic conditions. The climatic variation of the last 20 years (2000-2020) is not yet quantified in available climatic masks. Future climate predictions inferred using Intergovernmental Panel on Climate Change (IPCC) data are up to 2100 and project those last 20 years through interpolation. That is why we decided to keep the species occurrence data until 2019.

To test the effects of climate change on potential species distribution, we used future climate scenarios for 2050 (the midpoint for the 2041-2060 period) and 2070 (the mid-point for the 2061-2080 period), with two contrasting emission scenarios (IPCC 2014): (1) IPCC Fifth Assessment Report-Coupled Model Intercomparison Project, Phase 5 (AR-CMIP5) / Representative Concentration Pathway (RCP) 4.5 (lower energy demand) and (2) IPCC AR-CMIP5 / RCP 8.5 (i.e., maximum power requirement and balanced emissions from fossil fuels and non-fossil fuels). We also used three different Atmosphere-Ocean General Circulation Models (AOGCMs) in the future climate models simulations: CCSM4, MRI, and MIROC (https://esgf-node.llnl.gov/projects/ cmip5/).

\section{Niche-based models building}

Ecological niche modeling (ENM) approaches were used to predict current and future potential distributions of the Mato Grosso Antbird. Niche-based models calculate relationships between known occurrence data and environmental predictors (usually climate) to represent tolerable conditions for species survival and to infer habitat suitability values in areas where species occurrence is still unknown (Franklin 2010, Peterson et al. 2011).

To build ecological niche models, we assumed niche stability over time (Peterson et al. 2011, Stigall 2012). It is difficult to predict how species will respond to climates that do not currently exist because their response depends on their adaptive capacity and evolutionary rate (Peterson et al. 2002, Prieto-Torres et al. 2020), which are not yet known. Therefore, to predict the species' potential distribution in current and future climate scenarios, we used an ensemble forecasting method based on the use of different mathematical algorithms and future climate simulations to model niche species. The combined use of different algorithms usually increases the reliability of models because it considers a wide range of distribution patterns (Araújo and New 2007, Diniz-Filho et al. 2009), and the ensemble approach is currently the one most recommended for niche-based modeling (Araújo et al. 2019, Hao et al. 2019). Hence, we used four algorithms: (1) Bioclim (Envelope Score; Nix 1986), (2) Domain (Gower Distance; Carpenter et al. 1993), (3) Maximum Entropy (MAXENT v3.3.3k; Phillips and Dudík 2008), and (4) Support Vector Machines (SVM; Tax and Duin 2004). The entire niche-based analysis was performed using the R packages "dismo" and "kernlab" (Karatzoglou et al. 2004, Hijmans et al. 2015).

To evaluate the models, we divided the occurrence points into two subsets by means of bootstrapping: $75 \%$ of occurrence points were allocated to training and $25 \%$ to testing. Because training and testing points are subsets of the same point-occurrence data, we randomized the two subsets 10 times to minimize spatial structure in training and testing datasets, thereby enabling less biased evaluations. Thus, we built 10 replications of each algorithm, totaling 40 models (10 replications X 4 algorithms). The models were built using the current climate scenario and projected for each future scenario.

The model outputs were then transformed into binary maps based on threshold values, which were calculated using maximum sensitivity and specificity. These thresholds values maximize the accuracy of presence-absence and have proved to be effective in presence-only modeling (Liu et al. 2016). To evaluate the models, we calculated the values of true skill statistics (TSS). Because TSS values are threshold dependent, we estimated the values of maximum sensitivity and specificity (Liu et al. 2016). TSS values range from -1 to 1 (Allouche et al. 2006). Values that are negative or close to zero indicate that the forecasts are no different from randomly generated models, whereas forecasts with values close to 1 indicate good models, and values above 0.5 are adopted to indicate the most suitable models (Allouche et al. 2006).

The final habitat suitability maps were built using the frequency ensemble approach. To this end, we overlapped the binary maps pertaining to each algorithm (replicates) using their respective threshold values, and then added up the maps of the same algorithm and between the algorithms to obtain the final consensus map showing the frequencies of occurrence predicted by all the models. The values in the cells indicate the frequencies of occurrence in all the generated models, ranging from 0 to 40 (4 algorithms x 10 repetitions). To calculate final species suitability maps for each temporal and emission scenario, we divided the values of frequencies of occurrence by the total number of generated models (4 algorithms $x 10$ repetitions) resulting in maps with values from 0 (low environmental suitability) to 1 (high environmental suitability). We created separate ensemble maps for current and future scenarios (based on the ensemble of the three AOGCMs - CCSM4, MRI, and MIROC). To manage the raster datasets, we used the "raster" (Hijmans 2017), "rgdal" (Bivand et al. 2020), and "data.table" packages (Dowle and Srivnivasan 2020). 


\section{Effects of climate change on species redistribution}

To test latitudinal, elevation (altitudinal), longitudinal, and slope shifts in species distribution over time, we converted final environmental suitability maps into presence-absence maps, considering values of $>10 \%$ quantile of suitability as presence and values of $<10 \%$ quantile as absence. Thus, we obtained the values of elevation $(m)$, slope, latitude (decimal degrees), and longitude (decimal degrees) for each site predicted to be presence in each scenario (present, 2050 RCP 4.5, 2070 RCP 4.5, 2050 RCP 8.5, and 2070 RCP8.5). Non-parametric Kruskal-Wallis tests followed by Dunn's post hoc test were performed to determine if dependent variables (elevation, slope, latitude, and longitude) differed between scenarios (present, 2050 RCP 4.5, 2070 RCP 4.5, 2050 RCP 8.5, and 2070 RCP 8.5). The magnitude of shifts in dependent variables over time were identified using the chi-square $\left(\chi^{2}\right)$ value provided by the Kruskal-Wallis test.

Elevation and slope values were obtained from https://www. earthenv.org/DEM. Kruskal-Wallis tests were performed using the "kruskal.test" function of the R stats package (R Core Team 2020), whereas Dunn's test was calculated using the "dunnTest" function of R, with Bonferroni p-values adjusted using the R FSA package (Ogle et al. 2020). Graphs were produced using the "ggplot" function from the ggplot2 package in R (Wickham 2016). All the analyses were performed using the $R$ program ( $R$ Core Team 2020), considering a significance of $\alpha<0.05$, and map projections were created using the QGIS program (QGIS Development Team 2020).

\section{RESULTS}

The ENMs for Cercomacra melanaria in the current scenario confirm that today's species distribution is restricted mainly to plains and wetlands, which are subject to the flood pulse (Fig. 3A). The ENMs for future scenarios indicate that the species' potential distribution will shift to higher lands and mountains (regions with higher slopes) in westward longitudes (Fig. 3B), but with a redistribution to the north (equatorial region) rather than the south (higher latitudes; Fig. 3B), as originally predicted (Fig. 2C). The model performance was considered adequate according to the TSS values (>0.5; Appendix 3, Appendix 4).

\section{Present and future distribution}

The current predictions indicate that the species is distributed along the floodplains of the Brazilian Pantanal and Bolivian Chaco, in addition to the central Bolivian lowland regions comprising most of the Santa Cruz and Beni states (Fig. 3A). For RCP 4.5 scenarios (2050 and 2070), the species' habitat suitability should decrease in Brazilian and Bolivian Pantanal lowlands, and the sites of highest habitat suitability should shift toward highlands at the edges of the Upper Paraguay River basin in Brazil and northeastern Bolivia, and to the eastern side of the Andean highlands (Fig. 3B, Appendix 5, Appendix 6). The RCP 8.5 (2050 and 2070) prediction indicates that the species' habitat suitability should dwindle further and shift to highland regions. Areas with the highest habitat suitability are restricted to small highlands of the Paraguay basin in the Brazilian State of Mato Grosso do Sul, in extreme northwestern Bolivia, and small regions bordering the Andean highlands (Fig. 3B, Appendix 5, Appendix 6). Additionally, the species' potential area of distribution will decrease in future conditions, regardless of the climate scenario (low or high greenhouse gas concentration), with a loss of approximately $92.97 \%(46,417,050 \mathrm{ha})$ in the most extreme scenario (RCP $8.52070-3,509,325$ ha) compared to the current distribution (present-49,926,375 ha; Fig. 4A and Table 1).

Fig. 3. Potential habitat suitability and distribution map of the Mato Grosso Antbird (Cercomacra melanaria) in different climate scenarios (present, year 2050, year 2070) and different concentrations of greenhouse gases (Representative Concentration Pathway; RCP 4.5 and RCP 8.5). A = current species habitat suitability, $\mathrm{B}=$ climate scenarios. The colors indicate habitat suitability for the species.

A
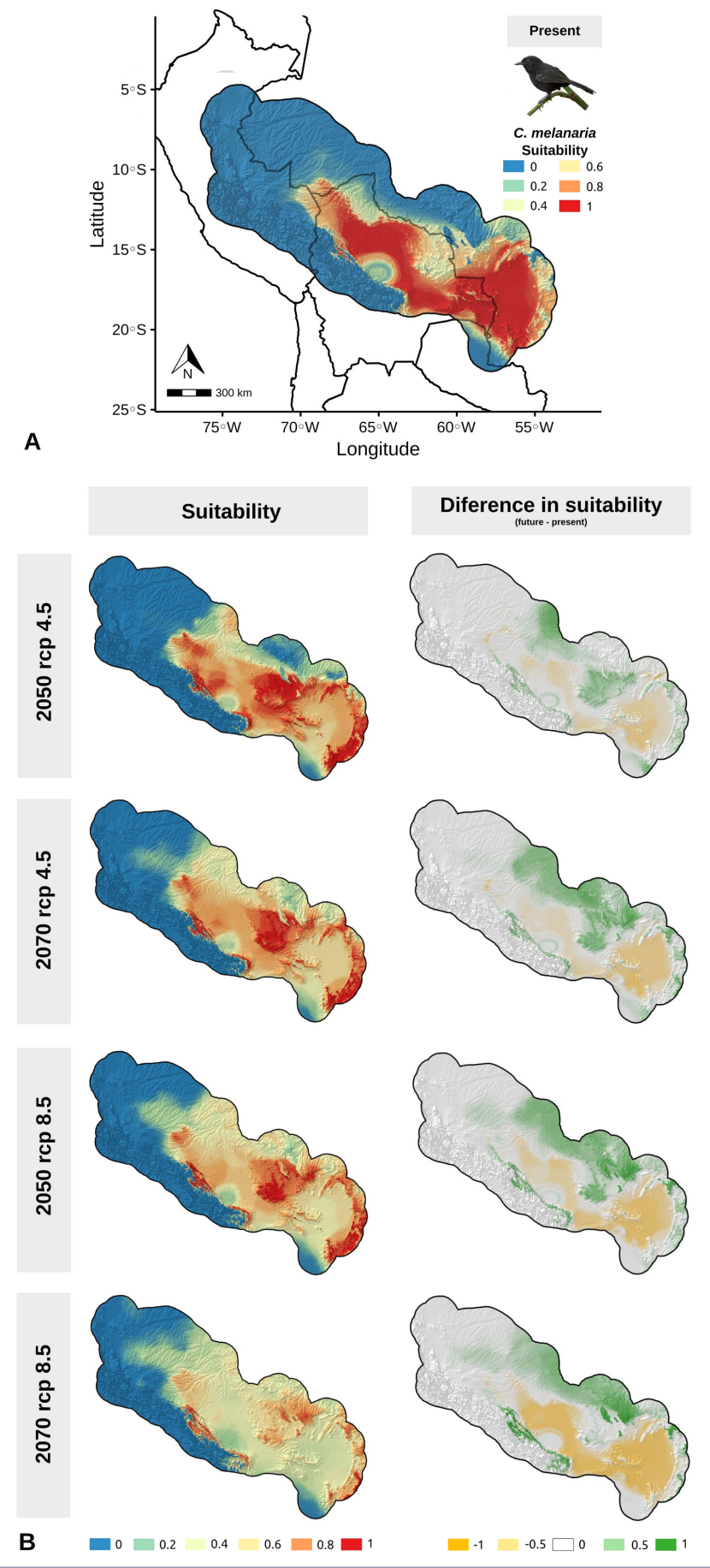
Table 1. Results of Mato Grosso Antbird (Cercomacra melanaria) potential distribution in the present and in future scenarios (Representative Concentration Pathway [RCP] 4.5 2050/2070 and RCP 8.5 2050/2070) of the different global circulation models (GCMs; CCSSM4, MIROC, MRI) and mean of the three GCMs (Atmosphere-Ocean GCM's ensemble). The distribution area of the species is shown by square kilometers $\left(\mathrm{km}^{2}\right)$, hectares (ha), and percentage $(\%)$.

\begin{tabular}{lccc}
\hline \hline Model & Area $\left(\mathrm{km}^{2}\right)$ & Area (ha) & $\%$ \\
\hline Present potential distribution area & 499263.80 & 49926375 & 100 \\
Models under RCP 4.5 & & & \\
CSSM4 2050 & 391695.80 & 39169575 & 78.46 \\
CSSM4 2070 & 268535.30 & 26853525 & 53.79 \\
MIROC 2050 & 303102.00 & 30310200 & 60.71 \\
MIROC 2070 & 232551.00 & 23255100 & 46.58 \\
MRI 2050 & 302474.30 & 30247425 & 60.59 \\
MRI 2070 & 249075.00 & 24907500 & 49.89 \\
AOGCMs ensemble 2050 & 309703.50 & 30970350 & 62.04 \\
AOGCMs ensemble 2070 & 223175.30 & 22317525 & 44.7 \\
Models under RCP 8.5 & & & \\
CSSM4 2050 & 221109.80 & 22110975 & 44.29 \\
CSSM4 2070 & 79420.50 & 7942050 & 15.91 \\
MIROC 2050 & 186259.50 & 18625950 & 37.31 \\
MIROC 2070 & 42970.50 & 4297050 & 8.61 \\
MRI 2050 & 182027.30 & 18202725 & 36.46 \\
MRI 2070 & 70065.00 & 7006500 & 14.03 \\
AOGCMs ensemble 2050 & 195959.30 & 19595925 & 39.25 \\
AOGCMs ensemble 2070 & 35093.30 & 3509325 & 7.03 \\
\hline
\end{tabular}

\section{Effects of climate change on species redistribution}

Future climate change will lead to significant shifts in species redistribution in terms of elevation $\left(\chi^{2}=25,697, \mathrm{df}=4, \mathrm{p}\right.$-value $=<0.001)$, slope $\left(\chi^{2}=17,024, \mathrm{df}=4\right.$, p-value $\left.=<0.001\right)$, latitude $\left(\chi^{2}=913.83, \mathrm{df}=4, \mathrm{p}\right.$-value $\left.=<0.001\right)$ and longitude $\left(\chi^{2}=520.5\right.$, $\mathrm{df}=4$, p-value $=<0.001$; Fig. 4, Appendix 7). Based on chi-square values, it is clear that major shift occurs in altitude direction, i.e., the species distribution from lowlands to highlands, followed by slope (plains lands to mountainous land), latitude (south to north - equatorial region), and longitude (east to west).

Currently, species occur in lowlands with an elevation of 0 to 150 $\mathrm{m}$, but the future climate scenarios show a gradual species' redistribution, mainly to highlands, ranging in elevation from 500 to $800 \mathrm{~m}$ (Fig. 4B). As for slope, the Mato Grosso Antbird today occurs in flat plains with low slopes (close to zero), while future climate scenarios indicate that the highest redistribution will occur toward areas with slopes of 0.5 to $2^{\circ}$ (max: 5.79; min: 0.014; mean: 0.755; Fig. 4C). Latitudinal redistribution is predicted to shift the species toward lower latitudes (equatorial areas), with an average change from $-17^{\circ}$ (present) to $-14^{\circ}$ (future scenarios; Fig. 4D). Lastly, according to future scenarios, the Mato Grosso Antbird will tend to shift westward (to higher longitudes), with a mean change of $-59^{\circ}$ (present) to $-62^{\circ}$ (future scenarios). However, in the most contrasting scenario (RCP 8.5, 2070), the habitat suitability distribution is greater at longitudes of $-67^{\circ}$ and $-55^{\circ}$, with an average of $-61^{\circ}$ (Fig. 4E; Appendix 8).

\section{DISCUSSION}

Our findings suggest a geographical shift of the Mato Grosso Antbird in response to future climate change. The species will suffer declining geographical distribution, with shifts in latitudinal, longitudinal, elevation, and slope patterns. The species currently occurs on plains and lowlands in South American wetlands. Its future northward and westward dispersion will cause the species to shift to highlands with steep slopes.

The future distribution scenarios suggest high species suitability at the headwaters of rivers in South American wetlands, mainly in Andean foothills (western Bolivia) and the border between Bolivia and Brazil (Fig. 4), corresponding to sites in Noel Kempff Mercado National Park (Bolivia) and the Serra Ricardo Franco State Park (Brazil). The upward shift to highlands will lead the species to water bodies and/or humid areas that match the current preference and tolerance of the species (Pinho et al. 2006, Bernardon et al. 2014).

Although the future predictions indicate upward shifts, colonization depends on the species' dispersal ability (e.g., forest corridors; Freeman et al. 2019). The Mato Grosso Antbird is a non-migratory and territorial species (Pinho et al. 2006) and, like most Thamnophilidae, has a low ability for long-distance flight (Zimmer et al. 2020). According to the hand-wing index (HWI), a morphological metric related to avian wing aspect ratio that is commonly used as a proxy of flight efficiency and dispersal ability (Sheard et al. 2020), the Mato Grosso Antbird's HWI (8.5) is considered low in comparison to that of other bird species (min 
Fig. 4. Effects of future climate change across elevation, slope, latitude, and longitude for the Mato Grosso Antbird (Cercomacra melanaria) in the Pantanal. The dashed line indicates the median of present scenario. Slope is represented as log-transformed data to facilitate graph visualization. $\mathrm{RCP}=$ Representative Concentration Pathway.
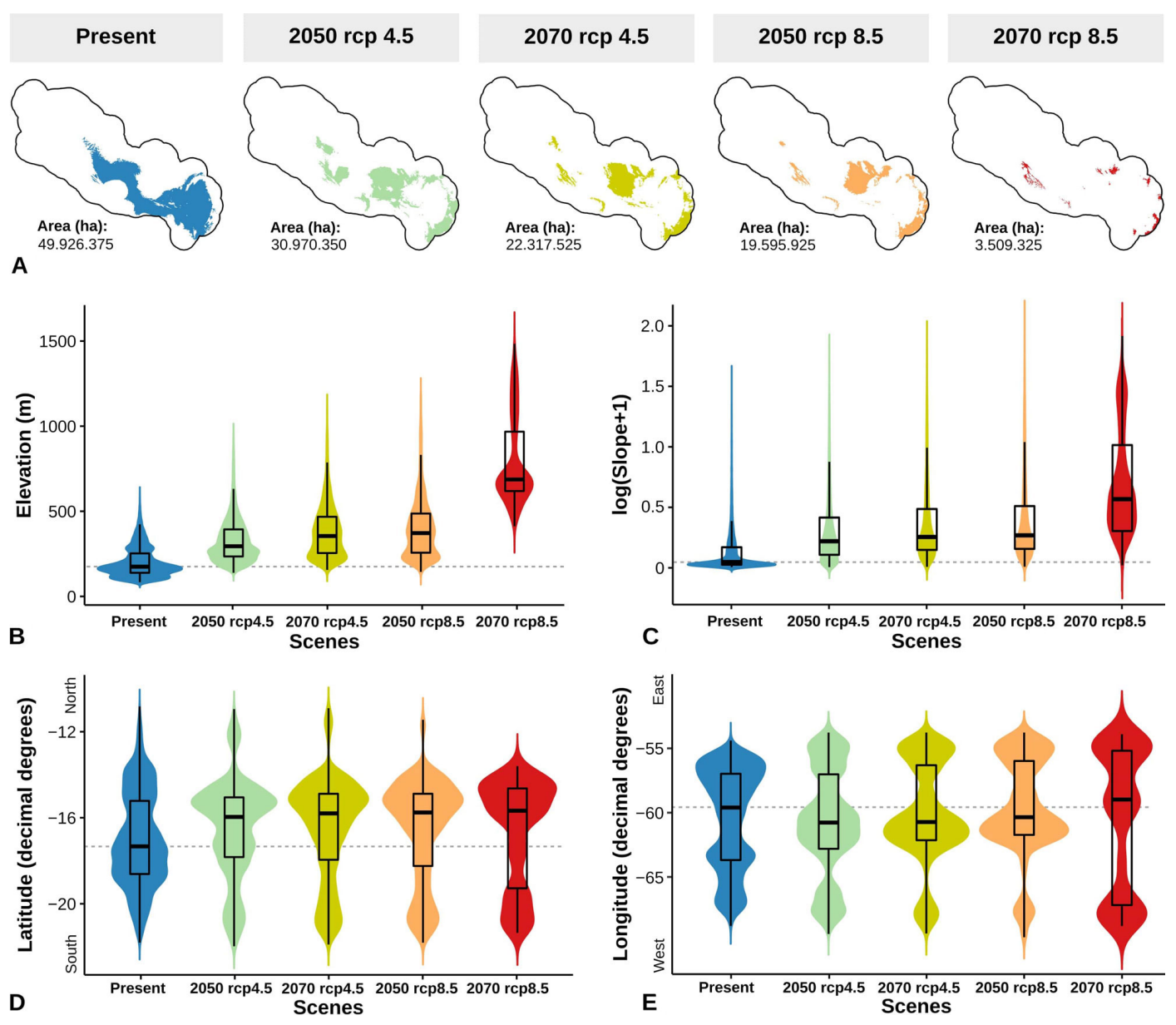

$=0.016-\max =74.80 ; \mathrm{SD} \pm 15.02)$. Hence, because of its low dispersal ability, the species will probably not move into its future suitable sites.

The move to higher lands may be facilitated by their proximity to the species' current distribution and by the existence of forest corridors, through which the species could hypothetically disperse more easily than by crossing open areas. Floodplain phytophysiognomies may also change in response to future global warming, increased climate seasonality, and/or anthropic disturbances such as deforestation. Guerra et al. (2020) infer a $3 \%$ loss in floodplain vegetation and a $10 \%$ loss in highland vegetation (where river headwaters are located) by 2050 . Thus, the species dispersal range is expected to decline, considering future landscape configurations.

The future success of the species' geographical mobility will also depend on narrow-scale processes such as biological interactions, nesting sites, and resource availability. Nesting sites depend directly on vegetation types - forest vegetation in humid sites with dense understory (Bernardon et al. 2014). Precipitation rates are important to maintain local humidity levels, but changes in precipitation seasonality and rising temperatures predicted for future global warming pose threats to floodplains (Enquist 2002, $\mathrm{Li}$ et al. 2009). Junk (2013) pointed out that precipitation rates in South America's floodplains will change dramatically in the future, with rainfall increasing in the rainy season and decreasing during the dry season, intensifying climate seasonality. Nesting depends mainly upon rainfall, given that the species' reproductive peak coincides with the onset of the rainy season because of higher availability of resources (invertebrates; Bernardon et al. 2014, Nóbrega et al. 2017). Thus, climate change also tends to directly affect the species' reproductive period.

Anthropogenic activities in and around river headwaters in the highlands represent another threat to the survival of the Mato Grosso Antbird. Pressure on the integrity of wetlands is increasing, mainly in the form of landscape modifications through mechanized agriculture and cattle raising, pollution, mining activities, and the construction of hydroelectric power plants (Junk 2013, Guerra et al. 2020, Medinas de Campos et al. 2020). 
The construction of 104 hydroelectric plants in the basin that feeds the Pantanal is being proposed. If all these proposed dams were built, the area flooded by new dams would triple and close an additional 11,000 to $12,000 \mathrm{~km}$ of river channels (Medinas de Campos et al. 2020). One of the main ecological impacts of small hydropower plants (SHPs) is habitat loss (Medinas de Campos et al. 2020). The construction of these SHPs will affect mainly the water bodies and wetlands of the UPB plateau, corresponding to the most suitable locations for the Mato Grosso Antbird in the scenarios of future climate change.

The UPB plateau has also been subjected to landscape modifications by mechanized agriculture since the 1970s, highlighting the rapid and recent increase in land use conversion (SOS-Pantanal et al. 2017, Guerra et al. 2020). The expansion of monocultures in Pantanal highlands has caused soil erosion and silted up rivers, changing their flow and hydrological indices in lowlands, as has been observed in the Upper Taquari River basin (Assine 2005, Galdino et al. 2006). Loss of native vegetation through agriculture or hydropower facilities could diminish the suitability of these areas for the species, affecting the availability of food and nesting sites.

In the absence of quantitative data on population trends, a criterion for extinction risk assessment under future climate change is to quantify losses in species distribution area $\left(\mathrm{km}^{2}\right)$. The IUCN Red List system is designed to account for uncertainty and allow the use of inference when appropriate (IUCN 2019). Forest loss data are also used to estimate extinction risk at local and regional scales. Forest loss is used as a proxy for population decline under criterion A of the Red List and calculation of area of occupation under criterion B (Tracewsky et al. 2016). According to Tracewsky et al. (2016), any species with a restricted home range and insufficient population data, such as the Mato Grosso Antbird, is considered at high risk of extinction, given its limited areas of occupation resulting from the paucity of remaining forest cover inside its range.

In view of the estimated future scenario for the distribution of the species, we have to consider that the current scenario of protected areas (PAs) may not be well balanced or representative. In Brazil, which is home to the largest range of the Mato Grosso Antbird, only $5.37 \%$ of the Pantanal is protected by Conservation Units, and this is one of the biomes least safeguarded by PAs in the country (MMA 2012, Chaves et al. 2018). The Pantanal is the world's largest continental wetland (Chardonnet et al. 2002, Harris et al. 2005), with four Ramsar sites (Ramsar Sites Information Service 2010). Nevertheless, the PAs do not cover the range needed to meet the area's biodiversity needs because $95 \%$ of the land in the Pantanal is privately owned and used mostly for ranching (Harris et al. 2005).

The threats are continuous. Between August and November 2020, $30 \%$ of this biome was destroyed by wildfires (Libonati et al. 2020), including protected areas and traditional communities. This was a destruction of unimaginable and catastrophic proportions, which revealed a scenario of extreme seasonality (longer dry season) that had already been predicted for the Pantanal region in climate change studies (Junk 2013, Marengo et al. 2015). Moreover, this tragedy also underscores the inability of the current government to manage threats within its own conservation areas (Ferrante and Fearnside 2019, Grasel et al.
2019), and the firefighting efforts were financed and carried out mostly by private individuals (M. F. Zuchetto, personal observation).

Although the current configuration of most PAs is not yet sufficiently representative, the sub-region of Chiquitano, Bolivia and the sub-Andean foothills were identified in a study as having some of the highest values of protected area coverage $(17.3 \%$ and $11.7 \%$, respectively, of extent considered as PAs; Prieto-Torres et al. 2018). This region coincides with some of the areas that we estimate as suitable in the future for the Mato Grosso Antbird. Therefore, there is an unequivocal need to increase the area and connectivity between PA networks to maximize long-term biodiversity conservation efforts (Prieto-Torres et al. 2018, Saura et al. 2018). Such an expansion would also connect the plains to areas of higher altitude, where most species are likely to find suitable areas considering a pessimistic scenario of climate change (Seimon et al. 2007, Şekercioğlu et al. 2008, 2012, Jankowski et al. 2013, Atauchi et al. 2020). Hence, the inclusion of the effects of climate change in the identification of priority areas for conservation helps to enhance the effectiveness of PA networks (Hannah et al. 2007; Triviño et al. 2018).

This study contributes by producing information about the distribution of a species with a restricted range, which is considered of least concern (LC), possibly because of data deficiency. This indicates that extinctions occur not only because of the disappearance of species classified as threatened, but also because of the disappearance of species with data deficiency. Therefore, in this paper we add knowledge to discuss the conservation status of the species.

\section{CONCLUSION}

The loss of ! 93\% of the species' suitable distribution area (the most drastic future scenario, RCP 8.5 2070) and all the dangers we have listed here constitute a threatening scenario for the Mato Grosso Antbird. The scenario may become worse than predicted if one considers the fact that the species' low dispersal ability makes future suitable sites practically inaccessible. This makes it imperative to reassess the conservation status of the species, which is currently considered of LC.

The species response to future climate change depends on all the factors discussed above. Likewise, our findings also highlight the inherent risk of South American floodplain biodiversity in future climate scenarios.

Responses to this article can be read online at: https://www.ace-eco.org/issues/responses.php/1893

\section{Acknowledgments:}

We are grateful for assistance and support from the National Institute of Science and Technology in Wetlands (INCT-INAU), the Higher Education Personnel Improvement Coordination (CAPES), and Mato Grosso State Research Support Foundation (FAPEMAT). We thank our collaborator Cristian Camilo Martinez Gonçalez for the invaluable assistance with the 
preliminary maps and data from Bolivia. Thanks also to the researchers Dennis Camacho, Miguel Angel Montenegro, Isabel Gomez, and Sofia Lothesberger for data collection from Bolivia and to Andressa Bach for reviewing the language of this manuscript.

\section{LITERATURE CITED}

Allouche, O., A. Tsoar, and R. Kadmon. 2006. Assessing the accuracy of species distribution models: prevalence, kappa and the true skill statistic (TSS). Journal of Applied Ecology 43:1223-1232. https://doi.org/10.1111/j.1365-2664.2006.01214.x

Araújo, M. B., R. P. Anderson, A. M. Barbosa, C. M. Beale, C. F. Dormann, R. Early, R. A. Garcia, A. Guisan, L. Maiorano, B. Naimi, R. B. O'Hara, N. E. Zimmermann, and C. Rahbek. 2019. Standards for distribution models in biodiversity assessments. Science Advances 5:1-12. https://doi.org/10.1126/ sciadv.aat 4858

Araújo, M. B., and M. New. 2007. Ensemble forecasting of species distributions. Trends in Ecology and Evolution 22:42-47. https:// doi.org/10.1016/j.tree.2006.09.010

Assine, M. L. 2005. River avulsions on the Taquari megafan, Pantanal wetland, Brazil. Geomorphology 70:357-371. https:// doi.org/10.1016/j.geomorph.2005.02.013

Atauchi, P. J., C. Aucca-Chutas, G. Ferro, and D. A. Prieto-Torres. 2020. Present and future potential distribution of the endangered Anairetes alpinus (Passeriformes: Tyrannidae) under global climate change scenarios. Journal of Ornithology 161:723-738. https://doi.org/10.1007/s10336-020-01762-z

Barve, N., V. Barve, A. Jiménez-Valverde, A. Lira-Noriega, S. P. Maher, A. T. Peterson, J. Soberón, and F. Villalobos. 2011. The crucial role of the accessible area in ecological niche modeling and species distribution modeling. Ecological Modelling 222:1810-1819. https://doi.org/10.1016/j.ecolmodel.2011.02.011

Berg, M. P., E. T. Kiers, G. Driessen, M. van der Heijden, B. W. Kooi, F. Kuenen, M. Liefting, H. A. Verhoef, and J. Ellers. 2010. Adapt or disperse: understanding species persistence in a changing world. Global Change Biology 16:587-598. https://doi. org/10.1111/j.1365-2486.2009.02014.X

Bernardon, B., P. F. A. Nóbrega, and J. B. Pinho. 2014. Reproductive biology and nest-site selection of the Mato Grosso Antbird Cercomacra melanaria in the Brazilian Pantanal. Revista Brasileira de Ornitologia 22:270-277. [online] URL: http://www. revbrasilornitol.com.br/BJO/article/view/23_3_artigo5

BirdLife International. 2018. Cercomacra melanaria. The IUCN Red List of Threatened Species 2018: e.T22701692A130215657. https://dx.doi.org/10.2305/IUCN.UK.2018-2.RLTS.

T22701692A130215657.en

Bivand, R., T. Keitt, and B. Rowlingson. 2020. rgdal: bindings for the 'geospatial' data abstraction library. R. package version 1.5-16. [online] URL: https://CRAN.R-project.org/package= rgdal

Cardinale, B. J., J. E. Duffy, A. Gonzalez, D. U. Hooper, C. Perrings, P. Venail, A. Narwani, G. M. Mace, D. Tilman, D. A. Wardle, A. P. Kinzig, G. C. Daily, M. Loreau, J. B. Grace, A.
Larigauderie, D. S. Srivastava, and S. Naeem. 2012. Biodiversity loss and its impact on humanity. Nature 486:59-67. https://doi. org/10.1038/nature11148

Carpenter, G., A. N. Gillison, and J. Winter. 1993. DOMAIN: a flexible modelling procedure for mapping potential distributions of plants and animals. Biodiversity and Conservation 2:667-680. https://doi.org/10.1007/BF00051966

Ceballos, G., P. R. Ehrlich, A. D. Barnosky, A. García, R. M. Pringle, and T. M. Palmer. 2015. Accelerated modern humaninduced species losses: entering the sixth mass extinction. Science Advances 1(5). https://doi.org/10.1126/sciadv.1400253

Chardonnet, Ph., B. des Clers, J. Fischer, R. Gerhold, F. Jori, and F. Lamarque. 2002. The value of wildlife. Revue Scientifique et Technique 21:15-51. https://doi.org/10.20506/rst.21.1.1323

Chaves, J. V. B., and J. dos S. V. da Silva. 2018. Evolução das unidades de conservação no Pantanal no período de 1998 a 2018. Pages 678-685 in Anais $7^{\circ}$ Simpósio de Geotecnologias no Pantanal. Jardim, Mato Grosso, Brazil. [online] URL https:// www.alice.cnptia.embrapa.br/alice/bitstream/doc/1099248/1/ PLEvolucaoGeopantanal.pdf

Chen, I. C., H. J. Shiu, S. Benedick, J. D. Holloway, V. K. Chey, H. S. Barlow, J. K. Hill, and C. D. Thomas. 2009. Elevation increases in moth assemblages over 42 years on a tropical mountain. Proceedings of the National Academy of Sciences of the United States of America 106:1479-1483. https://doi. org/10.1073/pnas.0809320106

Colwell, R. K., G. Brehm, C. L. Cardelús, A. C. Gilman, and J. T. Longino. 2008. Global warming, elevational range shifts, and lowland biotic attrition in the wet tropics. Science 322:258-261. https://doi.org/10.1126/science.1162547

Crick, H. Q. P., S. R. Baillie, and D. I. Leech. 2003. The UK nest record scheme: its value for science and conservation. Bird Study 50:254-270. https://doi.org/10.1080/00063650309461318

Crutzen P. J. 2006. The "Anthropocene". Pages 13-18 in E. Ehlers, and T. Krafft, editors. Earth system science in the anthropocene. Springer, Heidelberg, Germany. [online] URL https://link springer.com/content/pdf/10.1007\%2Fb137853.pdf

de Piacentini, V. Q., A. Aleixo, C. E. Agne, G. N. Maurício, J. F. Pacheco, Gustavo A. Bravo, G. R. R. Brito, L. N. Naka, F. Olmos, S. Posso, L. F. Silveira, G. S. Betini, E. Carrano, I. Franz, A. C. Lees, L. M. Lima, D. Pioli, F. Schunck, F. R. do Amaral, G. A. Bencke, M. Cohn-Haft, L. F. A. Figueiredo, F. C. Straube, and E. Cesari. 2015. Annotated checklist of the birds of Brazil by the Brazilian Ornithological Records Committee. Revista Brasileira de Ornitologia 23:91-298. https://doi.org/10.1007/BF03544294

Devictor, V., R. Julliard, and D. Couvet. 2008. Birds are tracking climate warming, but not fast enough. Proceedings of the Royal Society B 275:2743-2748. https://doi.org/10.1098/rspb.2008.0878

Díaz-Almeyda, E. M., C. Prada, A. H. Ohdera, H. Moran, D. J. Civitello, R. Iglesias-Prieto, T. A. Carlo, T. C. Lajeunesse, and M. Medina. 2017. Intraspecific and interspecific variation in thermotolerance and photoacclimation in Symbiodinium dinoflagellates. Proceedings of the Royal Society B 284:20171767. https://doi.org/10.1098/rspb.2017.1767 
Diniz-Filho, J. A. F., L. M. Bini, T. F. Rangel, R. D. Loyola, C. Hof, D. Nogués-Bravo, and M. B. Araújo. 2009. Partitioning and mapping uncertainties in ensembles of forecasts of species turnover under climate change. Ecography 32:897-906. https:// doi.org/10.1111/j.1600-0587.2009.06196.X

Dirzo, R., and P. H. Raven. 2003. Global state of biodiversity and loss. Annual Review of Environment and Resources 28:137-167. https://doi.org/10.1146/annurev.energy.28.050302.105532

Dirzo, R., H. S. Young, M. Galetti, G. Ceballos, N. J. B. Isaac, and B. Collen. 2014. Defaunation in the Anthropocene. Science 345:401-406. https://doi.org/10.1126/science.1251817

Dowle, M., and A. Srinivasan. 2020. data.table: extension of 'data.frame.' R. package 1.13.0. [online] URL: https://CRAN.Rproject.org/package $=$ data.table

Enquist, C. A. F. 2002. Predicted regional impacts of climate change on the geographical distribution and diversity of tropical forests in Costa Rica. Journal of Biogeography 29:519-534. https://doi.org/10.1046/j.1365-2699.2002.00695.x

Fei, S., J. M. Desprez, K. M. Potter, I. Jo, J. A. Knott, and C. M. Oswalt. 2017. Divergence of species responses to climate change. Science Advances 3:e1603055. https://doi.org/10.1126/sciadv.1603055

Ferrante, L., and P. M. Fearnside. 2019. Brazil's new president and "ruralists" threaten Amazonia's environment, traditional peoples and the global climate. Environmental Conservation 46:261-263. https://doi.org/10.1017/S0376892919000213

Francou, B., M. Vuille, P. Wagnon, J. Mendoza, and J. E. Sicart. 2003. Tropical climate change recorded by a glacier in the central Andes during the last decades of the twentieth century: Chacaltaya, Bolivia, $16^{\circ} \mathrm{S}$. Journal of Geophysical Research 108:1-12. https://doi.org/10.1029/2002jd002959

Franklin, J. 2010. Mapping species distributions: spatial inference and prediction. Cambridge University Press, Cambridge, UK. https://doi.org/10.1017/CBO9780511810602

Freeman, B., J. Sunnarborg, and A. T. Peterson. 2019. Effects of climate change on the distributional potential of three rangerestricted West African bird species. Condor 121:1-10. https://doi. org/10.1093/condor/duz012

Galdino, S., L. M. Vieira, and L. A. Pellegrin. 2006. Environmental and socioeconomic impacts in the Taquari River Basin - Pantanal. Embrapa Pantanal, Corumbá, Mato Grosso do Sul, Brazil. [online] URL: https://ainfo.cnptia.embrapa.br/ digital/bitstream/item/38652/1/Livro025.pdf

GBIF.org. 2019. GBIF occurrence download. Global Biodiversity Information Facility, Copenhagen, Denmark. https://doi.org/10.15468/dl.zr39py

Graham, C. H., N. Silva, and J. Velásquez-Tibatá. 2010. Evaluating the potential causes of range limits of birds of the Colombian Andes. Journal of Biogeography 37:1863-1875. https://doi.org/10.1111/j.1365-2699.2010.02356.x

Grasel, D., P. M. Fearnside, A. S. Rovai, J. R. S. Vitule, R. R. Rodrigues, R. P. Mormul, F. D. F. Sampaio, and J. A. Jarenkow. 2019. Brazil's Native Vegetation Protection Law jeopardizes wetland conservation: a comment on Maltchik et al.
Environmental Conservation 46:121-123. https://doi.org/10.1017/ S0376892918000474

Guerra, A., F. de O. Roque, L. C. Garcia, J. M. Ochao-Quintero, P. T. S. de Oliveira, R. D. Guariento, and I. M. D. Rosa. 2020. Drivers and projections of vegetation loss in the Pantanal and surrounding ecosystems. Land Use Policy 91:104388. https://doi. org/10.1016/j.landusepol.2019.104388

Hannah, L., G. Midgley, S. Andelman, M. Araújo, G. Hughes, E. Martinez-Meyer, R. Pearson, and P. Williams. 2007. Protected area needs in a changing climate. Frontiers in Ecology and the Environment 5:131-138. [online] URL: https://www.jstor.org/ stable/20440608

Hao, T., J. Elith, G. Guillera-Arroita, and J. J. Lahoz-Monfort. 2019. A review of evidence about use and performance of species distribution modelling ensembles like BIOMOD. Diversity and Distributions 25:839-852. https://doi.org/10.1111/ddi.12892

Harris, M. B., W. Tomas, G. Mourão, C. J. Da Silva, E. Guimarães, F. Sonoda, and E. Fachim. 2005. Safeguarding the Pantanal wetlands: threats and conservation initiatives. Conservation Biology 19:714-720. https://doi.org/10.1111/j.1523-1739.2005.00708 $\mathrm{x}$

Hijmans, R. J. 2017. Raster: geographic data analysis and modeling. [online] URL: http://CRAN.R-project.org/package= $\underline{\text { raster }}$

Hijmans, R. J., S. E. Cameron, J. L. Parra, P. G. Jones, and A. Jarvis. 2005. Very high resolution interpolated climate surfaces for global land areas. International Journal of Climatology 25:1965-1978. https://doi.org/10.1002/joc.1276

Hijmans, R. J., S. Phillips, J. Leathwick, and J. Elith. 2015. dismo: species distribution modeling. [online] URL: https://CRAN.Rproject.org/package $=$ dismo

INaturalist.org. 2019. Mato Grosso Antbird Cercomacra melanaria. [online] URL: https://www.inaturalist.org/taxa/15737Cercomacra-melanaria

Intergovernmental Panel on Climate Change (IPCC). 2014. Climate change 2014: synthesis report. Contribution of Working Groups I, II and III to the Fifth Assessment Report of the Intergovernmental Panel on Climate Change. Core Writing Team, R. K. Pachauri, and L. A. Meyer, editors. IPCC, Geneva, Switzerland. [online] URL: https://epic.awi.de/id/eprint/37530/

International Union for Conservation of Nature (IUCN). Standards and Petitions Subcommittee. 2019. Guidelines for using the IUCN Red List categories and criteria. Version 14. [online] URL: http://www.iucnredlist.org/documents/RedListGuidelines. pdf

Jankowski, J. E., C. L. Merkord, W. F. Rios, K. G. Cabrera, N. S. Revilla, and M. R. Silman. 2013. The relationship of tropical bird communities to tree species composition and vegetation structure along an Andean elevational gradient. Journal of Biogeography 40:950-962. https://doi.org/10.1111/jbi.12041

Junk, W. J. 2013. Current state of knowledge regarding South America wetlands and their future under global climate change. Aquatic Sciences 75:113-131. https://doi.org/10.1007/s00027-012-0253-8 
Karatzoglou, A., A. Smola, K. Hornik, and A. Zeileis. 2004. kernlab - an S4 package for kernel methods in R. Journal of Statistical Software 11:1-20. https://doi.org/10.18637/jss.v011.i09

Kelly, A. E., and M. L. Goulden. 2008. Rapid shifts in plant distribution with recent climate change. Proceedings of the National Academy of Sciences of the United States of America 105:11823-11826. https://doi.org/10.1073/pnas.0802891105

Kinzelbach, R. K. 1995. Vogelwelt und klimaverÃände-rung im 16. jahrhundert. Naturwissenschaften 82: 499-508. https://doi. org/10.1007/BF01134485

Lee, A. T. K., and H. Nel. 2020. BirdLasser: the influence of a mobile app on a citizen science project. African Zoology 55:155-160. https://doi.org/10.1080/15627020.2020.1717376

Li, J., D. W. Hilbert, T. Parker, and S. Williams. 2009. How do species respond to climate change along an elevation gradient? A case study of the grey-headed robin (Heteromyias albispecularis). Global Change Biology 15:255-267. https://doi.org/10.1111/ j.1365-2486.2008.01737.x

Libonati, R., J. A. Rodrigues, and F. Lemos. 2020. Nota técnica LASA - Área queimada Pantanal: situação até 15 de novembro 2020. Laboratório de Aplicações de Satélites Ambientais, Departamento de Meteorologia, Rio de Janeiro, Brazil. https:// doi.org/10.13140/RG.2.2.12810.90564

Liu, C., G. Newell, and M. White. 2016. On the selection of thresholds for predicting species occurrence with presence-only data. Ecology and Evolution 6:337-348. https://doi.org/10.1002/ ece 3.1878

Marengo, J. A., G. S. Oliveira, and L. M. Alves. 2015. Climate change scenarios in the Pantanal. Pages 227-238 in I. Bergier and M. L. Assine, editors. Dynamics of the Pantanal Wetland in South America. Springer International, Switzerland. https://doi. org/10.1007/698_2015_357

Medinas de Campos, M., H. M. Tritico, P. Girard, P. Zeilhofer, S. K. Hamilton, and I. Fantin-Cruz. 2020. Predicted impacts of proposed hydroelectric facilities on fish migration routes upstream from the Pantanal wetland (Brazil). River Research and Applications 36:452-464. https://doi.org/10.1002/rra.3588

Ménétriés, E. 1835. Monographie de la famille des Myotherinae où sont décrites les espèces qui ornent le Musée d'Académie impériale des Sciences. Mémoires de l'Académie des Sciences de St. Pétersburg, 6th serie 3:443-544. [online] URL: https://www. biodiversitylibrary.org/page/28731626

Ministério do Meio Ambiente (MMA). 2012. Cadastro Nacional de Unidades de Conservação. Brasilia, Brasil. [online] URL: https://antigo.mma.gov.br/areas-protegidas/cadastro-nacional-deucs/itemlist/category/130-cadastro-nacional-de-uc-s.html

Morrone, J. J. 2014. Biogeographical regionalisation of the neotropical region. Zootaxa 3782:1-110. https://doi.org/10.11646/ zootaxa.3782.1.1

Nix, H.A. 1986. A biogeographic analysis of Australian elapid snakes. Pages 4-15 in R. Longmore, editor. Atlas of elapid snakes of Australia. Australian Government Publishing Service, Canberra, Australia.
Nóbrega, P. F. A., J. B. de Pinho, and C. Duca. 2017. Population viability analysis of the Mato Grosso Antbird (Cercomacra melanaria) in the Pantanal of Mato Grosso, Brazil. Revista Brasileira de Ornitologia 25:169-175. https://doi.org/10.1007/ BF03544395

Nunes, A. P. 2011. Quantas espécies de aves ocorrem no Pantanal brasileiro? Atualidades Ornitológicas. 160:45-54. [online] URL: http://www.ao.com.br/download/AO160_45.pdf

Ogle, D.H., J. C. Doll, P. Wheeler, and A. Dinno. 2020. FSA: Fisheries stock analysis. R package version 0.8.30. [online] URL: https://github.com/droglenc/FSA

Parmesan, C., and G. Yohe. 2003. A globally coherent fingerprint of climate change. Nature 421:37-42. https://doi.org/10.1038/ nature 01286

Pearce-Higgins, J. W., and R. E. Green. 2014. Birds and climate change: impacts and conservation responses. Cambridge University Press, Cambridge, UK. https://doi.org/10.1017/ CBO9781139047791

Pecl, G. T., M. B. Araújo, J. D. Bell, J. Blanchard, T. C. Bonebrake, I. Chen, T. D. Clark, R. K. Colwell, F. Danielsen, B. Evengård, L. Falconi, S. Ferrier, S. Frusher, R. A. Garcia, R. B. Griffis, A. J. Hobday, C. Janion-Scheepers, M. A. Jarzyna, S. Jennings, J. Lenoir, H. I. Linnetved, V. Y. Martin, P. C. McCormack, J. McDonald, N. J. Mitchell, T. Mustonen, J. M. Pandolfi, N. Pettorelli, E. Popova, S. A. Robinson, B. R. Scheffers, J. D. Shaw, C. J. B. Sorte, J. M. Strugnell, J. M. Sunday, M. N. Tuanmu, A. Vergés, C. Villanueva, T. Wernberg, E. Wapstra, and S. E. Williams. 2017. Biodiversity redistribution under climate change: impacts on ecosystems and human well-being. Science 355:1-9. https://doi.org/10.1126/science.aai9214

Peterson, A. T., M. A. Ortega-Huerta, J. Bartley, V. SánchezCordero, J. Soberón, R. H. Buddemeler, and D. R. B. Stockwell. 2002. Future projections for Mexican faunas under global climate change scenarios. Nature 416:626-629. https://doi.org/10.1038/416626a

Peterson, A. T., J. Soberón, R. G. Pearson, R. P. Anderson, E. Martínez-Meyer, M. Nakamura, and M.B. Araújo. 2011. Ecological niches and geographic distributions. Princeton University Press, Princeton, New Jersey, USA.

Phillips, S. J., and M. Dudík. 2008. Modeling of species distributions with Maxent: new extensions and a comprehensive evaluation. Ecography 31:161-175. https://doi.org/10.1111/ j.0906-7590.2008.5203.x

Pinho, J. B., L. E. Lopes, D. H. de Morais, and A. M. Fernandes. 2006. Life history of the Mato Grosso Antbird Cercomacra melanaria in the Brazilian Pantanal. Ibis 148:321-329. https://doi. org/10.1111/j.1474-919X.2006.00542.x

Prieto-Torres, D. A., A. Lira-Noriega, and A. G. NavarroSigüenza. 2020. Climate change promotes species loss and uneven modification of richness patterns in the avifauna associated to Neotropical seasonally dry forests. Perspectives in Ecology and Conservation 18:19-30. https://doi.org/10.1016/j.pecon.2020.01.002

Prieto-Torres, D. A., J. Nori, and O. R. Rojas-Soto. 2018. Identifying priority conservation areas for birds associated to 
endangered Neotropical dry forests. Biological Conservation 228:205-214. https://doi.org/10.1016/j.biocon.2018.10.025

QGIS Development Team. 2020. QGIS geographic information system. Open Source Geospatial Foundation Project. [online] URL: http://qgis.osgeo.org

R Core Team. 2020. R: A language and environment for statistical computing. R Foundation for Statistical Computing, Vienna, Austria. [online] URL: https://www.R-project.org/

Ramsar Sites Information Service. 2010. Annotated list of wetlands of international importance, Brazil. [online] URL: https://rsis.ramsar.org/sites/default/files/rsiswp_search/exports/RamsarSites-annotated-summary-Brazil.pdf?1611261955

Revelle, W. 2020. psych: Procedures for personality and psychological research, version 2.0.9. Northwestern University, Evanston, Illinois, USA. [online] URL: https://CRAN.R-project. org/package $=$ psych .

Root, T. L., J. T. Price, K. R. Hall, S. H. Schneider, C. Rosenzweig, and J. A. Pounds. 2003. Fingerprints of global warming on wild animals and plants. Nature 421:57-60. https://doi.org/10.1038/ nature 01333

Santillán, V., M. Quitián, B. A. Tinoco, E. Zárate, M. Schleuning, K. Böhning-Gaese, and E. L. Neuschulz. 2020. Direct and indirect effects of elevation, climate and vegetation structure on bird communities on a tropical mountain. Acta Oecologica 102:103500. https://doi.org/10.1016/j.actao.2019.103500

Saura, S., B. Bertzky, L. Bastin, L. Battistella, A. Mandrici, and G. Dubois. 2018. Protected area connectivity: shortfalls in global targets and country-level priorities. Biological Conservation 219:53-67. https://doi.org/10.1016/j.biocon.2017.12.020

Seimon, T. A., A. Seimon, P. Daszak, S. R. P. Halloy, L. M. Schloegel, C. A. Aguilar, P. Sowell, A. D. Hyatt, B. Konecky, and J. E. Simmons. 2007. Upward range extension of Andean anurans and chytridiomycosis to extreme elevations in response to tropical deglaciation. Global Change Biology 13:288-299. https://doi. org/10.1111/j.1365-2486.2006.01278.X

Şekercioğlu, C. H. 2006. Increasing awareness of avian ecological function. Trends in Ecology and Evolution 21:464-471. https:// doi.org/10.1016/j.tree.2006.05.007

Şekercioğlu, C. H., R. B. Primack, and J. Wormworth. 2012. The effects of climate change on tropical birds. Biological Conservation 148:1-18. https://doi.org/10.1016/j.biocon.2011.10.019

Şekercioğlu, C. H., S. H. Schneider, J. P. Fay, and S. R. Loarie. 2008. Climate change, elevational range shifts, and bird extinctions. Conservation Biology 22:140-150. https://doi. org/10.1111/j.1523-1739.2007.00852.x

Sheard, C., M. H. C. Neate-Clegg, N. Alioravainen, S. E. I. Jones, C. Vincent, H. E. A. Macgregor, T. P. Bregman, S. Claramunt, and J. A. Tobias. 2020. Ecological drivers of global gradients in avian dispersal inferred from wing morphology. Nature Communications 11:2463. https://doi.org/10.1038/s41467-020-16313-6
Sobral-souza, T., R. B. Francini, and M. S. Lima-Ribeiro. 2015. Species extinction risk might increase out of reserves: allowances for conservation of threatened butterfly Actinote quadra (Lepidoptera: Nymphalidae) under global warming. Natureza \& Conservação 13:159-165. https://doi.org/10.1016/j.ncon.2015.11.009

SOS-Pantanal, WWF-Brasil, Conservation-International, ECOA, Fundación-AVINA, (2017). Monitoramento das alterações da cobertura vegetal e uso do solo na Bacia Do Alto Paraguai Porção Brasileira-período de análise: 2016 a 2017. Embrapa Pantanal, Corumbá, Mato Grosso do Sul, Brasil. [online] URL: https:// www.embrapa.br/documents/1354999/1529097/BAP+-+Mapping+ $\mathrm{da}+\mathrm{Bacia}+\mathrm{do}+$ Alto+Paraguay+-+sum $\% \mathrm{C} 3 \%$ A1rio+executivo/a2312a90c14f-4f39-b43d-61d6dea43556

Stigall, A. L. 2012. Using ecological niche modelling to evaluate niche stability in deep time. Journal of Biogeography 39:772-781. https://doi.org/10.1111/j.1365-2699.2011.02651.x

Sullivan, B. L., J. L. Aycrigg, J. H. Barry, R. E. Bonney, N. Bruns, C. B. Cooper, T. Damoulas, A. A. Dhondt, T. Dietterich, A. Farnsworth, D. Fink, J. W. Fitzpatrick, T. Fredericks, J. Gerbracht, C. Gomes, W. M. Hochachka, M. J. Iliff, C. Lagoze, F. A. La Sorte, M. Merrifield, W. Morris, T. B. Phillips, M. Reynolds, A. D. Rodewald, K. V. Rosenberg, N. M. Trautmann, A. Wiggins, D. W. Winkler, W. Wong, C. L. Wood, J. Yu, and S. Kelling. 2014. The eBird enterprise: an integrated approach to development and application of citizen science. Biological Conservation 169:31-40. https://doi.org/10.1016/j.biocon.2013.11.003

Sunday, J. M., A. E. Bates, and N. K. Dulvy. 2012. Thermal tolerance and the global redistribution of animals. Nature Climate Change 2:686-690. https://doi.org/10.1038/nclimate1539

Tax, D. M. J., and R. P. W. Duin. 2004. Support vector data description. Machine Learning 54:45-66. https://doi.org/10.1023/ B:MACH.0000008084.60811.49

Tracewski, Ł., S. H. M. Butchart, M. Di Marco, G. F. Ficetola, C. Rondinini, A. Symes, H. Wheatley, A. E. Beresford, and G. M. Buchanan. 2016. Toward quantification of the impact of 21stcentury deforestation on the extinction risk of terrestrial vertebrates. Conservation Biology 30:1070-1079. https://doi. org/10.1111/cobi.12715

Triviño, M., H. Kujala, M. B. Araújo, and M. Cabeza. 2018. Planning for the future: identifying conservation priority areas for Iberian birds under climate change. Landscape Ecology 33:659-673. https://doi.org/10.1007/s10980-018-0626-Z

Walsberg, G. E. 1993. Thermal consequences of diurnal microhabitat selection in a small bird. Ornis Scandinavica 24:174-182. https://doi.org/10.2307/3676733

Wickham H. 2016. ggplot2: elegant graphics for data analysis. Springer-Verlag, New York, New York, USA.

Wormworth, J., and C.H. Şekercioğlu. 2011. Winged sentinels: birds and climate change. Cambridge University Press, Melbourne, AU. https://doi.org/10.1017/CBO9781139150026 
Zimmer, K., M. L. Isler, and E. de Juana. 2020. Mato Grosso Antbird (Cercomacra melanaria), version 1.0. In J. del Hoyo, A. Elliott, J. Sargatal, D. A. Christie, and E. de Juana, editors. Birds of the world. Cornell Lab of Ornithology, Ithaca, New York, USA. https://doi.org/10.2173/bow.magant1.01

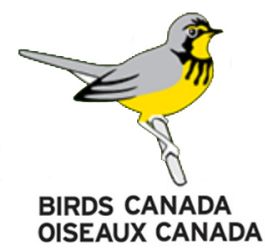




\section{Appendix 1}

Table A1.1: Occurence data from citizen science databases, digital databases (Global Biodiversity Information Facility - GBIF, Museo Nacional de História Natural, Colección Boliviana de Ornitología, Universidad Mayor de San Andrés -UMSA) and directly with researchers (Dennis Camacho - Asociación Boliviana de Ornitología - ASBOR, Miguel Angel Montenegro - Museo de Historia Natural Noel Kempff Mercado/ Universidad Autónoma Gabriel René Moreno - UAGRM, Sofia Lothesberger and Isabel GomezUMSA).

$\begin{array}{lcccc}\text { Name } & \text { Longitude } & \text { Latitude } & \text { Year } & \text { Source } \\ \text { Cercomacra_melanaria } & -56.364 & -20.243 & 2019 & \text { gbif } \\ \text { Cercomacra_melanaria } & -56.876 & -16.758 & 2019 & \text { gbif } \\ \text { Cercomacra_melanaria } & -56.304 & -19.953 & 2018 & \text { gbif } \\ \text { Cercomacra_melanaria } & -58.161 & -20.078 & 2018 & \text { gbif } \\ \text { Cercomacra_melanaria } & -64.754 & -15.193 & 2018 & \text { gbif } \\ \text { Cercomacra_melanaria } & -56.409 & -20.225 & 2018 & \text { gbif } \\ \text { Cercomacra_melanaria } & -55.77 & -16.132 & 2018 & \text { gbif } \\ \text { Cercomacra_melanaria } & -57.039 & -19.556 & 2018 & \text { gbif } \\ \text { Cercomacra_melanaria } & -56.408 & -20.256 & 2018 & \text { gbif } \\ \text { Cercomacra_melanaria } & -55.791 & -20.478 & 2018 & \text { gbif } \\ \text { Cercomacra_melanaria } & -55.965 & -20.096 & 2018 & \text { gbif } \\ \text { Cercomacra_melanaria } & -55.823 & -16.344 & 2018 & \text { gbif } \\ \text { Cercomacra_melanaria } & -56.417 & -14.833 & 2018 & \text { gbif } \\ \text { Cercomacra_melanaria } & -56.775 & -17.365 & 2018 & \text { gbif } \\ \text { Cercomacra_melanaria } & -56.621 & -16.379 & 2018 & \text { gbif } \\ \text { Cercomacra_melanaria } & -64.746 & -14.997 & 2018 & \text { gbif } \\ \text { Cercomacra_melanaria } & -56.699 & -17.283 & 2018 & \text { gbif } \\ \text { Cercomacra_melanaria } & -56.745 & -16.503 & 2018 & \text { gbif } \\ \text { Cercomacra_melanaria } & -56.735 & -16.621 & 2018 & \text { gbif } \\ \text { Cercomacra_melanaria } & -56.718 & -17.315 & 2018 & \text { gbif } \\ \text { Cercomacra_melanaria } & -56.943 & -17.103 & 2018 & \text { gbif } \\ \text { Cercomacra_melanaria } & -56.693 & -17.322 & 2018 & \text { gbif } \\ \text { Cercomacra_melanaria } & -56.769 & -17.355 & 2018 & \text { gbif } \\ \text { Cercomacra_melanaria } & -56.832 & -17.409 & 2018 & \text { gbif } \\ \text { Cercomacra_melanaria } & -56.844 & -16.784 & 2018 & \text { gbif } \\ \text { Cercomacra_melanaria } & -56.712 & -16.512 & 2018 & \text { gbif } \\ \text { Cercomacra_melanaria } & -56.24 & -15.372 & 2018 & \text { gbif } \\ \text { Cercomacra_melanaria } & -56.427 & -20.241 & 2018 & \text { gbif } \\ \text { Cercomacra_melanaria } & -56.823 & -17.458 & 2018 & \text { gbif } \\ \text { Cercomacra_melanaria } & -56.753 & -16.598 & 2018 & \text { gbif }\end{array}$




\begin{tabular}{|c|c|c|c|c|}
\hline Cercomacra_melanaria & -56.838 & -17.299 & 2018 & gbif \\
\hline Cercomacra_melanaria & -65.051 & -14.005 & 2018 & gbif \\
\hline Cercomacra_melanaria & -56.386 & -16.525 & 2018 & gbif \\
\hline Cercomacra_melanaria & -56.577 & -17.168 & 2018 & gbif \\
\hline Cercomacra_melanaria & -56.595 & -17.331 & 2018 & gbif \\
\hline Cercomacra_melanaria & -56.615 & -20.086 & 2018 & gbif \\
\hline Cercomacra_melanaria & -64.856 & -14.877 & 2018 & gbif \\
\hline Cercomacra_melanaria & -64.907 & -14.74 & 2018 & gbif \\
\hline Cercomacra_melanaria & -64.974 & -14.796 & 2018 & gbif \\
\hline Cercomacra_melanaria & -55.944 & -20.141 & 2018 & gbif \\
\hline Cercomacra_melanaria & -64.813 & -14.911 & 2018 & gbif \\
\hline Cercomacra_melanaria & -56.399 & -16.472 & 2018 & gbif \\
\hline Cercomacra_melanaria & -56.641 & -16.562 & 2018 & bif \\
\hline Cercomacra_melanaria & -57.04 & -19.401 & 2018 & gbif \\
\hline Cercomacra_melanaria & -64.943 & -14.206 & 2018 & \\
\hline Cercomacra_melanaria & -64.889 & -14.849 & 2018 & gbif \\
\hline Cercomacra_melanaria & -56.873 & -20.737 & 2018 & gbif \\
\hline Cercomacra_melanaria & -57.038 & -19.575 & 2018 & oif \\
\hline Cercomacra_melanaria & -54.926 & -20.227 & 2018 & \\
\hline Cercomacra_melanaria & -56.729 & -16.534 & 2018 & gbif \\
\hline Cercomacra_melanaria & -56.594 & -16.404 & 2018 & gbif \\
\hline Cercomacra_melanaria & -56.551 & -17.414 & 2018 & \\
\hline Cercomacra_melanaria & -56.59 & -16.396 & 2018 & gbif \\
\hline Cercomacra_melanaria & -57.602 & -19.024 & 2018 & gbif \\
\hline Cercomacra_melanaria & -57.363 & -18.458 & 2018 & gbif \\
\hline Cercomacra_melanaria & -64.937 & -14.81 & 2018 & \\
\hline Cercomacra_melanaria & -57.382 & -18.39 & 2018 & gbif \\
\hline Cercomacra_melanaria & -57.384 & -18.168 & 2018 & gbif \\
\hline Cercomacra_melanaria & -57.492 & -18.078 & 2018 & gbif \\
\hline Cercomacra_melanaria & -57.655 & -18.997 & 2018 & if \\
\hline Cercomacra_melanaria & -56.138 & -15.545 & 2017 & gbif \\
\hline Cercomacra_melanaria & -56.691 & -16.457 & 2017 & gbif \\
\hline Cercomacra_melanaria & -56.736 & -17.312 & 2017 & gbif \\
\hline Cercomacra_melanaria & -56.674 & -16.41 & 2017 & if \\
\hline Cercomacra_melanaria & -64.479 & -13.553 & 2017 & gbif \\
\hline Cercomacra_melanaria & -56.929 & -17.117 & 2017 & gbif \\
\hline Cercomacra_melanaria & -56.706 & -16.61 & 2017 & \\
\hline Cercomacra_melanaria & -56.675 & -16.504 & 2017 & gbif \\
\hline Cercomacra_melanaria & -56.378 & -16.513 & 2017 & gbif \\
\hline Cercomacra_melanaria & -57.837 & -16.567 & 2017 & gbif \\
\hline Cercomacra_melanaria & -56.674 & -17.335 & 2017 & \\
\hline
\end{tabular}




\begin{tabular}{|c|c|c|c|c|}
\hline Cercomacra_melanaria & -56.713 & -20.536 & 2017 & gbif \\
\hline Cercomacra_melanaria & -56.298 & -16.367 & 2017 & gbif \\
\hline Cercomacra_melanaria & -63.07 & -17.766 & 2017 & gbif \\
\hline Cercomacra_melanaria & -58.204 & -19.966 & 2017 & gbif \\
\hline Cercomacra_melanaria & -56.648 & -16.362 & 2017 & gbif \\
\hline Cercomacra_melanaria & -56.674 & -16.453 & 2016 & gbif \\
\hline Cercomacra_melanaria & -55.613 & -19.507 & 2016 & gbif \\
\hline Cercomacra_melanaria & -56.624 & -16.273 & 2016 & gbif \\
\hline Cercomacra_melanaria & -56.669 & -16.592 & 2016 & gbif \\
\hline Cercomacra_melanaria & -55.39 & -19.285 & 2016 & gbif \\
\hline Cercomacra_melanaria & -56.32 & -15.722 & 2016 & bif \\
\hline Cercomacra_melanaria & -56.837 & -16.848 & 2016 & gbif \\
\hline Cercomacra_melanaria & -56.681 & -17.268 & 2016 & gbif \\
\hline Cercomacra_melanaria & -64.993 & -14.224 & 2016 & gbif \\
\hline Cercomacra_melanaria & -56.771 & -16.644 & 2016 & \\
\hline Cercomacra_melanaria & -65.015 & -14.209 & 2016 & gbif \\
\hline Cercomacra_melanaria & -56.91 & -17.25 & 2016 & gbif \\
\hline Cercomacra_melanaria & -57.516 & -19.203 & 2016 & oif \\
\hline Cercomacra_melanaria & -56.575 & -20.225 & 2015 & \\
\hline Cercomacra_melanaria & -57.844 & -21.1 & 2015 & gbif \\
\hline Cercomacra_melanaria & -58.133 & -20.383 & 2015 & gbif \\
\hline Cercomacra_melanaria & -64.74 & -15.153 & 2015 & if \\
\hline Cercomacra_melanaria & -64.891 & -14.892 & 2015 & gbif \\
\hline Cercomacra_melanaria & -56.141 & -15.755 & 2015 & gbif \\
\hline Cercomacra_melanaria & -65.213 & -13.693 & 2015 & gbif \\
\hline Cercomacra_melanaria & -56.641 & -16.33 & 2015 & \\
\hline Cercomacra_melanaria & -56.714 & -16.527 & 2014 & gbif \\
\hline Cercomacra_melanaria & -56.35 & -16.381 & 2014 & gbif \\
\hline Cercomacra_melanaria & -56.627 & -16.267 & 2014 & gbif \\
\hline Cercomacra_melanaria & -56.088 & -19.589 & 2014 & if \\
\hline Cercomacra_melanaria & -57.017 & -19.267 & 2014 & gbif \\
\hline Cercomacra_melanaria & -57.231 & -19.255 & 2013 & gbif \\
\hline Cercomacra_melanaria & -65.929 & -14.941 & 2013 & gbif \\
\hline Cercomacra_melanaria & -58.146 & -20.134 & 2013 & \\
\hline Cercomacra_melanaria & -56.842 & -16.701 & 2013 & gbif \\
\hline Cercomacra_melanaria & -55.863 & -16.346 & 2013 & gbif \\
\hline Cercomacra_melanaria & -57.787 & -18.969 & 2012 & \\
\hline Cercomacra_melanaria & -56.786 & -17.004 & 2012 & gbif \\
\hline Cercomacra_melanaria & -64.97 & -14.868 & 2012 & gbif \\
\hline Cercomacra_melanaria & -56.602 & -19.668 & 2012 & \\
\hline Cercomacra_melanaria & -55.767 & -19.829 & 2012 & \\
\hline
\end{tabular}




\begin{tabular}{|c|c|c|c|c|}
\hline Cercomacra_melanaria & -64.76 & -15.192 & 2012 & gbif \\
\hline Cercomacra_melanaria & -56.066 & -15.635 & 2012 & gbif \\
\hline Cercomacra_melanaria & -64.975 & -14.462 & 2011 & gbif \\
\hline Cercomacra_melanaria & -56.76 & -16.758 & 2011 & gbif \\
\hline Cercomacra_melanaria & -64.946 & -14.725 & 2011 & gbif \\
\hline Cercomacra_melanaria & -64.929 & -14.113 & 2011 & gbif \\
\hline Cercomacra_melanaria & -56.765 & -16.557 & 2010 & gbif \\
\hline Cercomacra_melanaria & -56.957 & -19.494 & 2010 & gbif \\
\hline Cercomacra_melanaria & -63.736 & -17.002 & 2010 & gbif \\
\hline Cercomacra_melanaria & -56.151 & -19.577 & 2010 & gbif \\
\hline Cercomacra_melanaria & -64.958 & -14.748 & 2010 & gbif \\
\hline Cercomacra_melanaria & -64.77 & -14.684 & 2010 & bif \\
\hline Cercomacra_melanaria & -58.269 & -20.184 & 2009 & gbif \\
\hline Cercomacra_melanaria & -55.507 & -20.459 & 2009 & bif \\
\hline Cercomacra_melanaria & -65.113 & -13.643 & 2009 & gbif \\
\hline Cercomacra_melanaria & -64.913 & -14.003 & 2008 & gbif \\
\hline Cercomacra_melanaria & -63.07 & -17.774 & 2008 & gbif \\
\hline Cercomacra_melanaria & -58.638 & -17.26 & 2008 & if \\
\hline Cercomacra_melanaria & -64.768 & -15.266 & 2007 & gbif \\
\hline Cercomacra_melanaria & -66.869 & -14.214 & 2007 & gbif \\
\hline Cercomacra_melanaria & -56.854 & -15.169 & 2007 & gbif \\
\hline Cercomacra_melanaria & -58.2 & -19.983 & 2006 & bif \\
\hline Cercomacra_melanaria & -58.17 & -20.23 & 2006 & gbif \\
\hline Cercomacra_melanaria & -56.426 & -17.665 & 2006 & gbif \\
\hline Cercomacra_melanaria & -56.667 & -21.009 & 2006 & bif \\
\hline Cercomacra_melanaria & -66.824 & -14.073 & 2006 & bif \\
\hline Cercomacra_melanaria & -57.87 & -21.036 & 2006 & gbif \\
\hline Cercomacra_melanaria & -64.509 & -13.805 & 2006 & gbif \\
\hline Cercomacra_melanaria & -63.829 & -13.232 & 2005 & oif \\
\hline Cercomacra_melanaria & -56.833 & -16.667 & 2005 & gbif \\
\hline Cercomacra_melanaria & -56.22 & -20.292 & 2004 & gbif \\
\hline Cercomacra_melanaria & -55.893 & -15.696 & 2003 & gbif \\
\hline Cercomacra_melanaria & -56.803 & -17.324 & 2003 & if \\
\hline Cercomacra_melanaria & -55.677 & -19.777 & 2003 & gbif \\
\hline Cercomacra_melanaria & -57.385 & -19.031 & 2002 & gbif \\
\hline Cercomacra_melanaria & -56.47 & -16.372 & 2001 & \\
\hline Cercomacra_melanaria & -62.509 & -19.175 & 2001 & if \\
\hline Cercomacra_melanaria & -62.521 & -18.959 & 2001 & gbif \\
\hline Cercomacra_melanaria & -61.959 & -18.391 & 2000 & gbif \\
\hline Cercomacra_melanaria & -56.845 & -16.825 & 2000 & gbif \\
\hline Cercomacra_melanaria & -58.3 & -19.92 & 1999 & gbif \\
\hline
\end{tabular}




\begin{tabular}{|c|c|c|c|c|}
\hline Cercomacra_melanaria & -58.133 & -20.1 & 1999 & gbif \\
\hline Cercomacra_melanaria & -64.981 & -13.915 & 1998 & gbif \\
\hline Cercomacra_melanaria & -60.31 & -20.31 & 1998 & gbif \\
\hline Cercomacra_melanaria & -66.288 & -14.645 & 1998 & gbif \\
\hline Cercomacra_melanaria & -58.417 & -20.05 & 1997 & gbif \\
\hline Cercomacra_melanaria & -64.611 & -13.264 & 1994 & gbif \\
\hline Cercomacra_melanaria & -63.161 & -17.948 & 1992 & gbif \\
\hline Cercomacra_melanaria & -58.633 & -17.267 & 1991 & gbif \\
\hline Cercomacra_melanaria & -57.571 & -19.021 & 2019 & inat \\
\hline Cercomacra_melanaria & -58.5 & -18.795 & 1969 & UMSA- Gomez, I. \\
\hline Cercomacra_melanaria & -58.191 & -19.703 & 1971 & UMSA- Gomez, I. \\
\hline Cercomacra_melanaria & -58.102 & -19.706 & 1972 & UMSA- Gomez, I. \\
\hline Cercomacra_melanaria & -58.116 & -19.829 & 1973 & UMSA- Gomez, I. \\
\hline Cercomacra_melanaria & -58.221 & -19.659 & 1977 & UMSA- Gomez, I. \\
\hline Cercomacra_melanaria & -57.992 & -18.987 & 1979 & UMSA- Gomez, I. \\
\hline Cercomacra_melanaria & -57.905 & -18.796 & 1982 & UMSA- Gomez, I. \\
\hline Cercomacra_melanaria & -57.962 & -18.886 & 1986 & UMSA- Gomez, I. \\
\hline Cercomacra_melanaria & -58.554 & -18.903 & 1989 & UMSA- Gomez, I. \\
\hline Cercomacra_melanaria & -58.572 & -18.793 & 1990 & UMSA- Gomez, I. \\
\hline Cercomacra_melanaria & -57.804 & -18.333 & 1991 & UMSA- Gomez, I. \\
\hline Cercomacra_melanaria & -57.858 & -18.491 & 1992 & UMSA- Gomez, I. \\
\hline Cercomacra_melanaria & -58.798 & -17.908 & 1992 & UMSA- Gomez, I. \\
\hline Cercomacra_melanaria & -58.872 & -17.946 & 1993 & UMSA- Gomez, I. \\
\hline Cercomacra_melanaria & -58.667 & -17.221 & 1993 & UMSA- Gomez, I. \\
\hline Cercomacra_melanaria & -58.771 & -17.284 & 1993 & UMSA- Gomez, I. \\
\hline Cercomacra_melanaria & -60.317 & -17.103 & 1994 & UMSA- Gomez, I. \\
\hline Cercomacra_melanaria & -60.267 & -17.026 & 1995 & UMSA- Gomez, I. \\
\hline Cercomacra_melanaria & -60.181 & -17.19 & 1995 & UMSA- Gomez, I. \\
\hline Cercomacra_melanaria & -62.169 & -18.824 & 1996 & UMSA- Gomez, I. \\
\hline Cercomacra_melanaria & -61.998 & -18.438 & 1996 & UMSA- Gomez, I. \\
\hline Cercomacra_melanaria & -61.684 & -18.21 & 1997 & UMSA- Gomez, I. \\
\hline Cercomacra_melanaria & -62.312 & -18.866 & 1997 & UMSA- Gomez, I. \\
\hline Cercomacra_melanaria & -62.883 & -17.781 & 1998 & UMSA- Gomez, I. \\
\hline Cercomacra_melanaria & -62.655 & -17.681 & 1999 & UMSA- Gomez, I. \\
\hline Cercomacra_melanaria & -62.698 & -17.896 & 1999 & UMSA- Gomez, I. \\
\hline Cercomacra_melanaria & -63.383 & -17.482 & 1999 & UMSA- Gomez, I. \\
\hline Cercomacra_melanaria & -63.411 & -17.082 & 2000 & UMSA- Gomez, I. \\
\hline Cercomacra_melanaria & -63.559 & -16.933 & 2000 & UMSA- Gomez, I. \\
\hline Cercomacra_melanaria & -64.862 & -16.814 & 2000 & UMSA- Gomez, I. \\
\hline Cercomacra_melanaria & -64.892 & -16.731 & 2000 & UMSA- Gomez, I. \\
\hline Cercomacra_melanaria & -64.785 & -16.749 & 2001 & UMSA- Gomez, I. \\
\hline
\end{tabular}




\begin{tabular}{|c|c|c|c|c|}
\hline Cercomacra_melanaria & -64.505 & -16.1 & 2004 & UMSA- Gomez, I. \\
\hline Cercomacra_melanaria & -64.517 & -15.922 & 2005 & UMSA- Gomez, I. \\
\hline Cercomacra_melanaria & -64.594 & -15.94 & 2005 & UMSA- Gomez, I. \\
\hline Cercomacra_melanaria & -64.035 & -15.52 & 2005 & UMSA- Gomez, I. \\
\hline Cercomacra_melanaria & -64.041 & -15.371 & 2005 & UMSA- Gomez, I. \\
\hline Cercomacra_melanaria & -64.13 & -15.472 & 2005 & UMSA- Gomez, I. \\
\hline Cercomacra_melanaria & -64.404 & -15.407 & 2006 & UMSA- Gomez, I. \\
\hline Cercomacra_melanaria & -64.344 & -15.317 & 2006 & UMSA- Gomez, I. \\
\hline Cercomacra_melanaria & -64.469 & -15.24 & 2006 & UMSA- Gomez, I. \\
\hline Cercomacra_melanaria & -64.755 & -15.383 & 2007 & UMSA- Gomez, I. \\
\hline Cercomacra_melanaria & -64.999 & -15.228 & 2007 & UMSA- Gomez, I. \\
\hline Cercomacra_melanaria & -64.927 & -15.103 & 2007 & UMSA- Gomez, I. \\
\hline Cercomacra_melanaria & -65.564 & -15.074 & 2008 & UMSA- Gomez, I. \\
\hline Cercomacra_melanaria & -64.541 & -15.014 & 2008 & UMSA- Gomez, I. \\
\hline Cercomacra_melanaria & -64.678 & -14.859 & 2008 & UMSA- Gomez, I. \\
\hline Cercomacra_melanaria & -64.428 & -14.919 & 2008 & UMSA- Gomez, I. \\
\hline Cercomacra_melanaria & -64.582 & -14.949 & 2008 & UMSA- Gomez, I. \\
\hline Cercomacra_melanaria & -64.672 & -14.58 & 2009 & UMSA- Gomez, I. \\
\hline Cercomacra_melanaria & -64.112 & -14.306 & 2009 & UMSA- Gomez, I. \\
\hline Cercomacra_melanaria & -63.482 & -13.878 & 2009 & UMSA- Gomez, I. \\
\hline Cercomacra_melanaria & -63.797 & -13.473 & 2009 & UMSA- Gomez, I. \\
\hline Cercomacra_melanaria & -63.857 & -13.521 & 2009 & UMSA- Gomez, I. \\
\hline Cercomacra_melanaria & -64.285 & -13.687 & 2010 & UMSA- Gomez, I. \\
\hline Cercomacra_melanaria & -64.374 & -13.414 & 2010 & UMSA- Gomez, I. \\
\hline Cercomacra_melanaria & -64.428 & -13.45 & 2010 & UMSA- Gomez, I. \\
\hline Cercomacra_melanaria & -64.749 & -13.783 & 2011 & UMSA- Gomez, I. \\
\hline Cercomacra_melanaria & -64.921 & -13.878 & 2011 & UMSA- Gomez, I. \\
\hline Cercomacra_melanaria & -64.856 & -13.83 & 2012 & UMSA- Gomez, I. \\
\hline Cercomacra_melanaria & -64.648 & -14.056 & 2012 & UMSA- Gomez, I. \\
\hline Cercomacra_melanaria & -64.808 & -14.217 & 2012 & UMSA- Gomez, I. \\
\hline Cercomacra_melanaria & -64.761 & -14.134 & 2012 & UMSA- Gomez, I. \\
\hline Cercomacra_melanaria & -64.606 & -14.288 & 2012 & UMSA- Gomez, I. \\
\hline Cercomacra_melanaria & -64.678 & -14.389 & 2012 & UMSA- Gomez, I. \\
\hline Cercomacra_melanaria & -65.623 & -15.014 & 2013 & UMSA- Gomez, I. \\
\hline Cercomacra_melanaria & -65.951 & -14.675 & 2013 & UMSA- Gomez, I. \\
\hline Cercomacra_melanaria & -66.052 & -14.604 & 2014 & UMSA- Gomez, I. \\
\hline Cercomacra_melanaria & -66.307 & -14.294 & 2014 & UMSA- Gomez, I. \\
\hline Cercomacra_melanaria & -66.409 & -14.33 & 2014 & UMSA- Gomez, I. \\
\hline Cercomacra_melanaria & -66.432 & -14.217 & 2014 & UMSA- Gomez, I. \\
\hline Cercomacra_melanaria & -66.313 & -14.223 & 2014 & UMSA- Gomez, I. \\
\hline Cercomacra_melanaria & -66.926 & -14.52 & 2014 & UMSA- Gomez, I. \\
\hline
\end{tabular}




\begin{tabular}{|c|c|c|c|c|}
\hline Cercomacra_melanaria & -66.908 & -14.455 & 2015 & UMSA- Gomez, I. \\
\hline Cercomacra_melanaria & -67.027 & -14.092 & 2015 & UMSA- Gomez, I. \\
\hline Cercomacra_melanaria & -67.009 & -13.967 & 2015 & UMSA- Gomez, I. \\
\hline Cercomacra_melanaria & -65.885 & -13.705 & 2015 & UMSA- Gomez, I. \\
\hline Cercomacra_melanaria & -67.072 & -14.3 & 2015 & UMSA- Gomez, I. \\
\hline Cercomacra_melanaria & -67.015 & -14.215 & 2016 & UMSA- Gomez, I. \\
\hline Cercomacra_melanaria & -67.101 & -14.043 & 2016 & UMSA- Gomez, I. \\
\hline Cercomacra_melanaria & -66.951 & -14.029 & 2016 & UMSA- Gomez, I. \\
\hline Cercomacra_melanaria & -66.815 & -14.136 & 2016 & UMSA- Gomez, I. \\
\hline Cercomacra_melanaria & -66.587 & -14.6 & 2016 & UMSA- Gomez, I. \\
\hline Cercomacra_melanaria & -66.48 & -14.693 & 2016 & UMSA- Gomez, I. \\
\hline Cercomacra_melanaria & -66.194 & -14.978 & 2017 & UMSA- Gomez, I. \\
\hline Cercomacra_melanaria & -66.094 & -15.114 & 2017 & UMSA- Gomez, I. \\
\hline Cercomacra_melanaria & -66.244 & -15.107 & 2017 & UMSA- Gomez, I. \\
\hline Cercomacra_melanaria & -65.067 & -15.185 & 2017 & UMSA- Gomez, I. \\
\hline Cercomacra_melanaria & -65.145 & -15.185 & 2017 & UMSA- Gomez, I. \\
\hline Cercomacra_melanaria & -64.524 & -15.549 & 2018 & UMSA- Gomez, I. \\
\hline Cercomacra_melanaria & -64.824 & -15.235 & 2018 & UMSA- Gomez, I. \\
\hline Cercomacra_melanaria & -65.067 & -14.843 & 2018 & UMSA- Gomez, I. \\
\hline Cercomacra_melanaria & -65.052 & -14.721 & 2018 & UMSA- Gomez, I. \\
\hline Cercomacra_melanaria & -65.052 & -14.636 & 2018 & UMSA- Gomez, I. \\
\hline Cercomacra_melanaria & -64.981 & -14.286 & 2018 & UMSA- Gomez, I. \\
\hline Cercomacra_melanaria & -65.074 & -14.286 & 2018 & UMSA- Gomez, I. \\
\hline Cercomacra_melanaria & -65.352 & -14.143 & 2017 & UMSA - Lothersberger, S. \\
\hline Cercomacra_melanaria & -65.059 & -13.95 & 2017 & UMSA - Lothersberger, S. \\
\hline Cercomacra_melanaria & -65.002 & -13.893 & 2017 & UMSA - Lothersberger, S. \\
\hline Cercomacra_melanaria & -64.988 & -13.986 & 2017 & UMSA - Lothersberger, S. \\
\hline Cercomacra_melanaria & -65.466 & -13.708 & 2017 & UMSA - Lothersberger, S \\
\hline Cercomacra_melanaria & -65.359 & -13.622 & 2017 & UMSA - Lothersberger, S \\
\hline Cercomacra_melanaria & -65.445 & -13.85 & 2017 & UMSA - Lothersberger, S \\
\hline Cercomacra_melanaria & -65.324 & -13.779 & 2017 & UMSA - Lothersberger, S. \\
\hline Cercomacra_melanaria & -64.631 & -13.793 & 2017 & UMSA - Lothersberger, S. \\
\hline Cercomacra_melanaria & -64.695 & -13.722 & 2017 & UMSA - Lothersberger, S \\
\hline Cercomacra_melanaria & -64.595 & -13.472 & 2017 & UMSA - Lothersberger, S \\
\hline Cercomacra_melanaria & -64.688 & -13.565 & 2017 & UMSA - Lothersberger, S. \\
\hline Cercomacra_melanaria & -64.703 & -13.408 & 2017 & UMSA - Lothersberger, S. \\
\hline Cercomacra_melanaria & -64.617 & -13.272 & 2017 & UMSA - Lothersberger, S. \\
\hline Cercomacra_melanaria & -64.681 & -13.322 & 2017 & UMSA - Lothersberger, S. \\
\hline Cercomacra_melanaria & -63.939 & -13.251 & 2017 & UMSA - Lothersberger, S. \\
\hline Cercomacra_melanaria & -63.946 & -13.122 & 2017 & UMSA - Lothersberger, S. \\
\hline Cercomacra_melanaria & -63.882 & -13.179 & 2018 & UMSA - Lothersberger, S. \\
\hline
\end{tabular}




$\begin{array}{lcccc}\text { Cercomacra_melanaria } & -63.767 & -17.127 & 2018 & \text { UMSA - Lothersberger, S. } \\ \text { Cercomacra_melanaria } & -63.71 & -17.07 & 2018 & \text { UMSA - Lothersberger, S. } \\ \text { Cercomacra_melanaria } & -63.782 & -17.206 & 2018 & \text { UMSA - Lothersberger, S. } \\ \text { Cercomacra_melanaria } & -63.896 & -17.555 & 2015 & \text { UAGRM- Montenegro, M. A. } \\ \text { Cercomacra_melanaria } & -63.953 & -17.748 & 2015 & \text { UAGRM- Montenegro, M. A. } \\ \text { Cercomacra_melanaria } & -64.024 & -17.755 & 2015 & \text { UAGRM- Montenegro, M. A. } \\ \text { Cercomacra_melanaria } & -63.989 & -17.648 & 2015 & \text { UAGRM- Montenegro, M. A. } \\ \text { Cercomacra_melanaria } & -63.189 & -17.934 & 2016 & \text { UAGRM- Montenegro, M. A. } \\ \text { Cercomacra_melanaria } & -63.175 & -17.784 & 2016 & \text { UAGRM- Montenegro, M. A. } \\ \text { Cercomacra_melanaria } & -63.268 & -17.941 & 2016 & \text { UAGRM- Montenegro, M. A. } \\ \text { Cercomacra_melanaria } & -62.689 & -19.039 & 2013 & \text { UAGRM- Montenegro, M. A. } \\ \text { Cercomacra_melanaria } & -62.618 & -19.224 & 2013 & \text { UAGRM- Montenegro, M. A. } \\ \text { Cercomacra_melanaria } & -62.618 & -19.346 & 2013 & \text { UAGRM- Montenegro, M. A. } \\ \text { Cercomacra_melanaria } & -62.668 & -19.281 & 2013 & \text { UAGRM- Montenegro, M. A. } \\ \text { Cercomacra_melanaria } & -62.561 & -19.139 & 2013 & \text { UAGRM- Montenegro, M. A. } \\ \text { Cercomacra_melanaria } & -62.653 & -18.967 & 2013 & \text { UAGRM- Montenegro, M. A. } \\ \text { Cercomacra_melanaria } & -61.875 & -18.518 & 2016 & \text { ASBOR - Camacho, D. } \\ \text { Cercomacra_melanaria } & -61.968 & -18.518 & 2016 & \text { ASBOR - Camacho, D. } \\ \text { Cercomacra_melanaria } & -61.875 & -18.389 & 2016 & \text { ASBOR - Camacho, D. } \\ \text { Cercomacra_melanaria } & -57.787 & -19.068 & 2017 & \text { ASBOR - Camacho, D. } \\ \text { Cercomacra_melanaria } & -57.77 & -18.906 & 2017 & \text { ASBOR - Camacho, D. } \\ \text { Cercomacra_melanaria } & -57.552 & -18.247 & 2017 & \text { ASBOR - Camacho, D. } \\ \text { Cercomacra_melanaria } & -58.592 & -17.325 & 2017 & \text { ASBOR - Camacho, D. } \\ \text { Cercomacra_melanaria } & -58.409 & -17.191 & 2017 & \text { ASBOR - Camacho, D. } \\ \text { Cercomacra_melanaria } & -58.663 & -17.421 & 2017 & \text { ASBOR - Camacho, D. }\end{array}$




\section{Appendix 2}

Table A2.2: Factorial analysis result with the 19 Bioclimatic variables.

\begin{tabular}{|c|c|c|c|c|}
\hline Bioclimatic variables & MR1 & MR4 & MR2 & MR3 \\
\hline BIO1 = Annual Mean Temperature & 0.97 & 0.15 & 0.16 & 0.02 \\
\hline $\mathrm{BIO} 2=$ Mean Diurnal Range & 0.68 & 0.47 & 0.06 & 0.24 \\
\hline $\mathrm{BIO} 3=$ Isothermality $(\mathrm{BIO} 2 / \mathrm{BIO} 7)(* 100)$ & 0.14 & 0.18 & 0.19 & 0.88 \\
\hline BIO4 = Temperature Seasonality & 0.04 & 0.1 & 0.27 & 0.96 \\
\hline BIO5 = Max Temperature of Warmest Month & 0.95 & 0.02 & 0.14 & 0.2 \\
\hline BIO6 = Min Temperature of Coldest Month & 0.92 & 0.26 & 0.17 & 0.24 \\
\hline $\mathrm{BIO} 7=$ Temperature Annual Range & 0.47 & 0.45 & 0.15 & 0.67 \\
\hline BIO8 = Mean Temperature of Wettest Quarter & 0.97 & 0.15 & 0.12 & 0.12 \\
\hline BIO9 = Mean Temperature of Driest Quarter & 0.95 & 0.17 & 0.19 & 0.18 \\
\hline BIO10 = Mean Temperature of Warmest Quarter & 0.98 & 0.14 & 0.12 & 0.11 \\
\hline BIO11 = Mean Temperature of Coldest Quarter & 0.94 & 0.17 & 0.2 & 0.2 \\
\hline BIO12 = Annual Precipitation & 0.26 & 0.45 & 0.79 & 0.32 \\
\hline BIO13 = Precipitation of Wettest Month & 0.19 & 0.18 & 0.94 & 0.21 \\
\hline BIO14 = Precipitation of Driest Month & 0.1 & 0.88 & 0.44 & 0.12 \\
\hline BIO15 = Precipitation Seasonality & 0.44 & 0.8 & 0 & 0.18 \\
\hline BIO16 = Precipitation of Wettest Quarter & 0.2 & 0.18 & 0.93 & 0.23 \\
\hline BIO17 = Precipitation of Driest Quarter & 0.13 & 0.87 & 0.44 & 0.16 \\
\hline BIO18 = Precipitation of Warmest Quarter & 0.17 & 0.44 & 0.75 & 0.02 \\
\hline BIO19 = Precipitation of Coldest Quarter & 0.2 & 0.8 & 0.43 & 0.17 \\
\hline
\end{tabular}




\section{Appendix 3}

Table A3.3: Result of model evaluation according to TSS (true skill statistic), Threshold and AUC value for each algorithm.

\begin{tabular}{lccr} 
Algorithm & Threshold & AUC & \multicolumn{1}{l}{ TSS } \\
& & & \\
BIOCLIM & 0.0475191 & 0.823 & 0.589 \\
BIOCLIM & 0.0475191 & 0.7969 & 0.533 \\
BIOCLIM & 0.0379952 & 0.8133 & 0.544 \\
BIOCLIM & 0.0284714 & 0.8294 & 0.611 \\
BIOCLIM & 0.0808524 & 0.8617 & 0.7 \\
BIOCLIM & 0.0665667 & 0.813 & 0.644 \\
BIOCLIM & 0.0713286 & 0.8563 & 0.6 \\
BIOCLIM & 0.0237095 & 0.8898 & 0.667 \\
BIOCLIM & 0.0475191 & 0.8101 & 0.556 \\
BIOCLIM & 0.0284714 & 0.8252 & 0.578 \\
GOWER & 0.5311748 & 0.8497 & 0.589 \\
GOWER & 0.5288443 & 0.7622 & 0.556 \\
GOWER & 0.5289337 & 0.7698 & 0.544 \\
GOWER & 0.5206949 & 0.8111 & 0.567 \\
GOWER & 0.551321 & 0.8322 & 0.6 \\
GOWER & 0.5283914 & 0.8126 & 0.578 \\
GOWER & 0.5099529 & 0.7926 & 0.544 \\
GOWER & 0.5359615 & 0.8822 & 0.7 \\
GOWER & 0.5234998 & 0.8028 & 0.533 \\
MAXENT & 0.429548 & 0.8737 & 0.689 \\
MAXENT & 0.5373038 & 0.8863 & 0.722 \\
MAXENT & 0.4750426 & 0.869 & 0.667 \\
MAXENT & 0.4994759 & 0.8674 & 0.678 \\
MAXENT & 0.471922 & 0.8673 & 0.744 \\
MAXENT & 0.4417572 & 0.8727 & 0.7 \\
MAXENT & 0.4527299 & 0.8936 & 0.678 \\
MAXENT & 0.498503 & 0.9109 & 0.744 \\
MAXENT & 0.5093525 & 0.8811 & 0.689 \\
MAXENT & 0.4060642 & 0.8758 & 0.656 \\
SVM & 0.618196 & 0.9141 & 0.722 \\
SVM & 0.6344363 & 0.9065 & 0.744 \\
SVM & 0.6196699 & 0.8826 & 0.711 \\
SVM & 0.707109 & 0.9181 & 0.744 \\
SVM & 0.4946061 & 0.8958 & 0.756 \\
SVM & 0.4008957 & 0.8931 & 0.722 \\
SVM & 0.6751981 & 0.9131 & 0.756
\end{tabular}


$\begin{array}{llll}\text { SVM } & 0.712212 & 0.9372 & 0.822\end{array}$

$\begin{array}{lllll}\text { SVM } & 0.8114853 & 0.8868 & 0.667\end{array}$

$\begin{array}{lllll}\text { SVM } & 0.6167689 & 0.8836 & 0.711\end{array}$ 


\section{Appendix 4}

Fig.A4.4: Result of model evaluation according to TSS (true skill statistic), Threshold and AUC value for each algorithm.

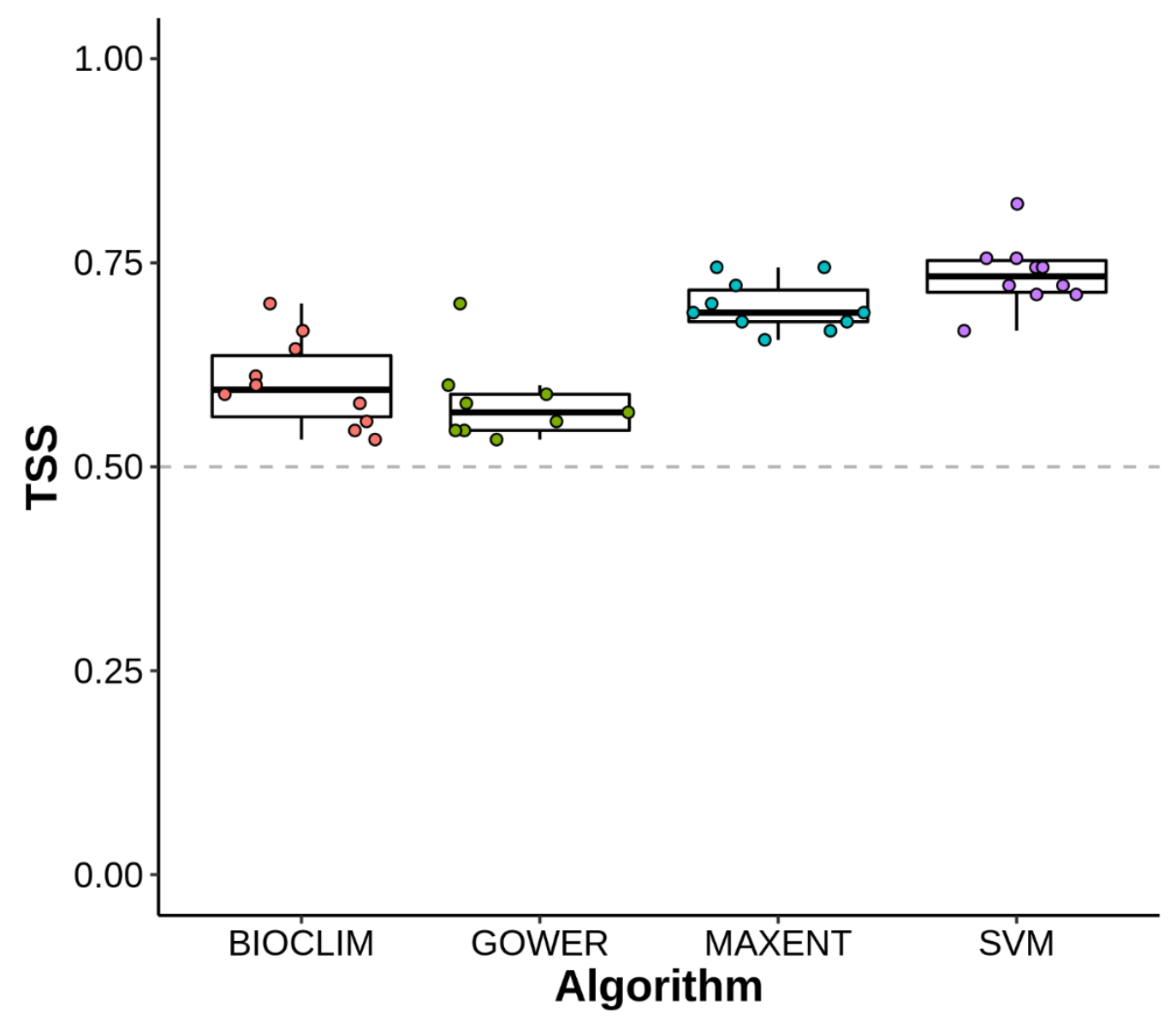




\section{Appendix 5}

Fig.A5.5: Potential distribution map of Mato Grosso Antbird suitability in different climate scenarios (present, year 2050, year 2070), different global circulation models (GCM) (CCSSM4, MIROC and MRI) and ensemble of the three GCMs.

\section{PRESENT}
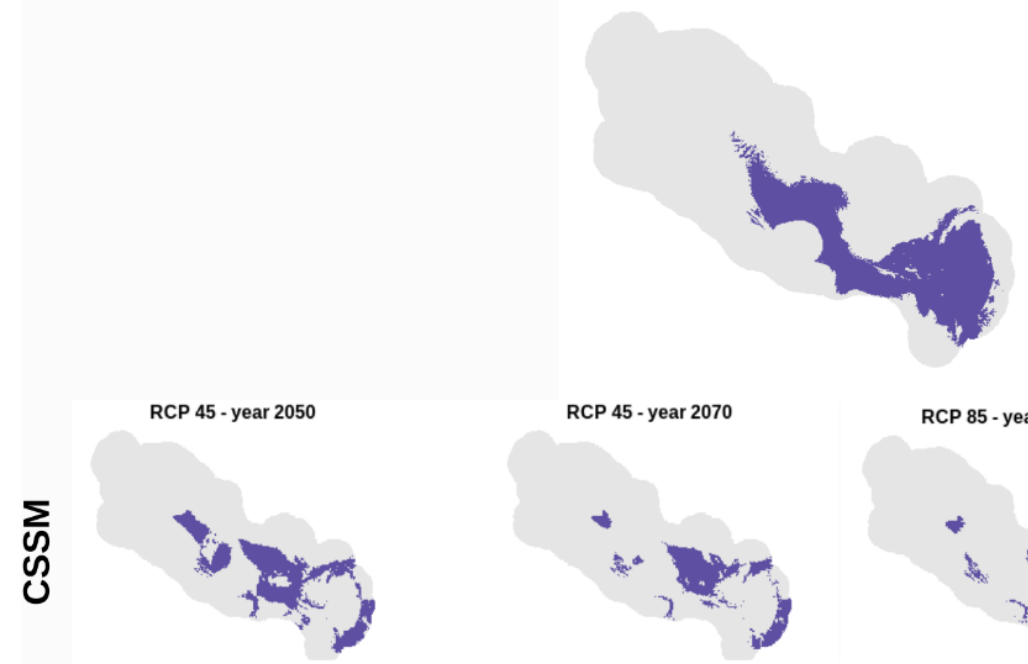

RCP 45 - year 2070

RCP 85 - year 2050

RCP 85 - year 2070
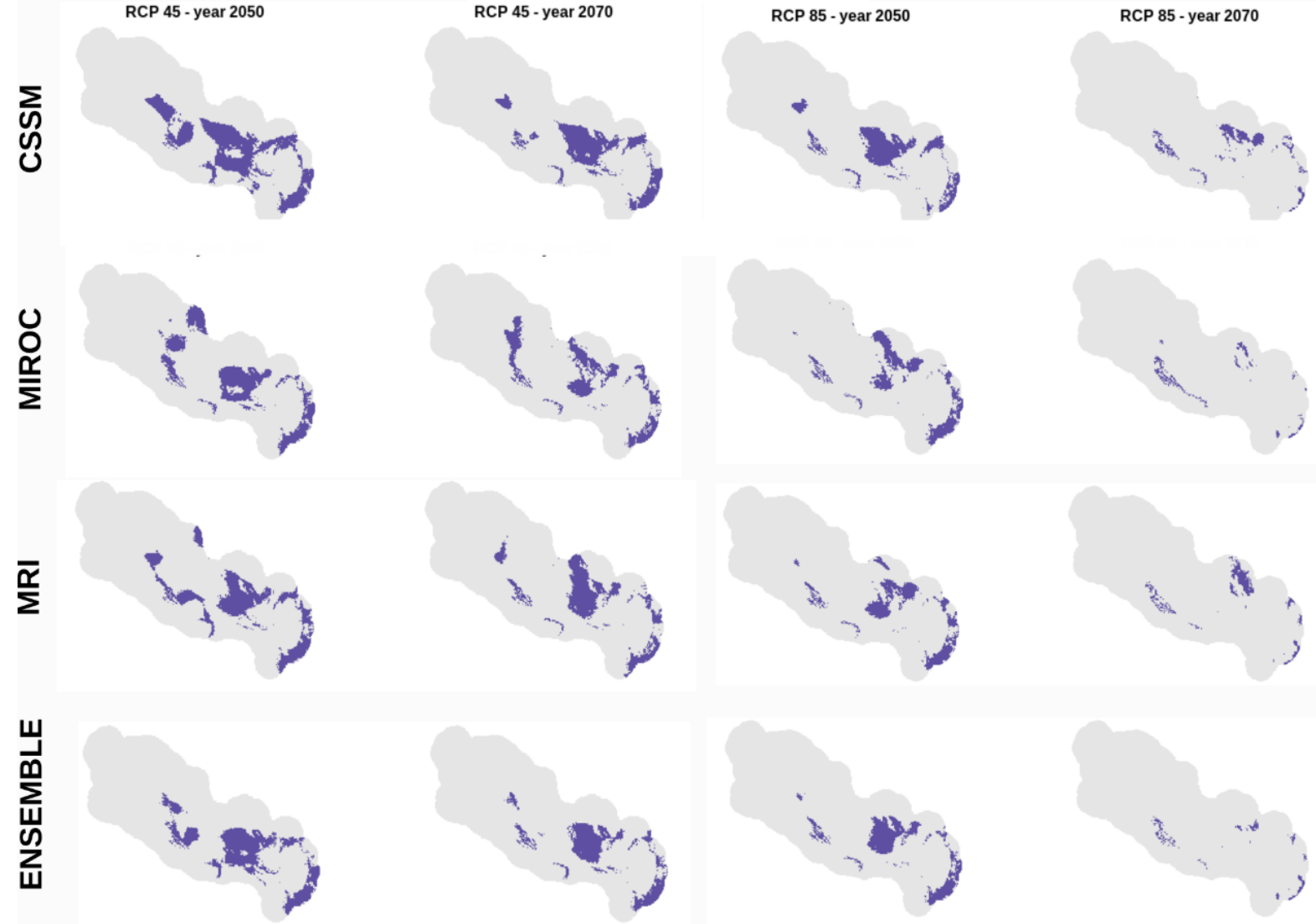


\section{Appendix 6}

Fig.A6.6: Potential distribution maps of Mato Grosso Antbird suitability in different climate scenarios (year 2050, year 2070) for each different global circulation models CCSSM4, MIROC and MRI. (RCP: Representative Concentration Pathway).

\section{AOGCM CC}

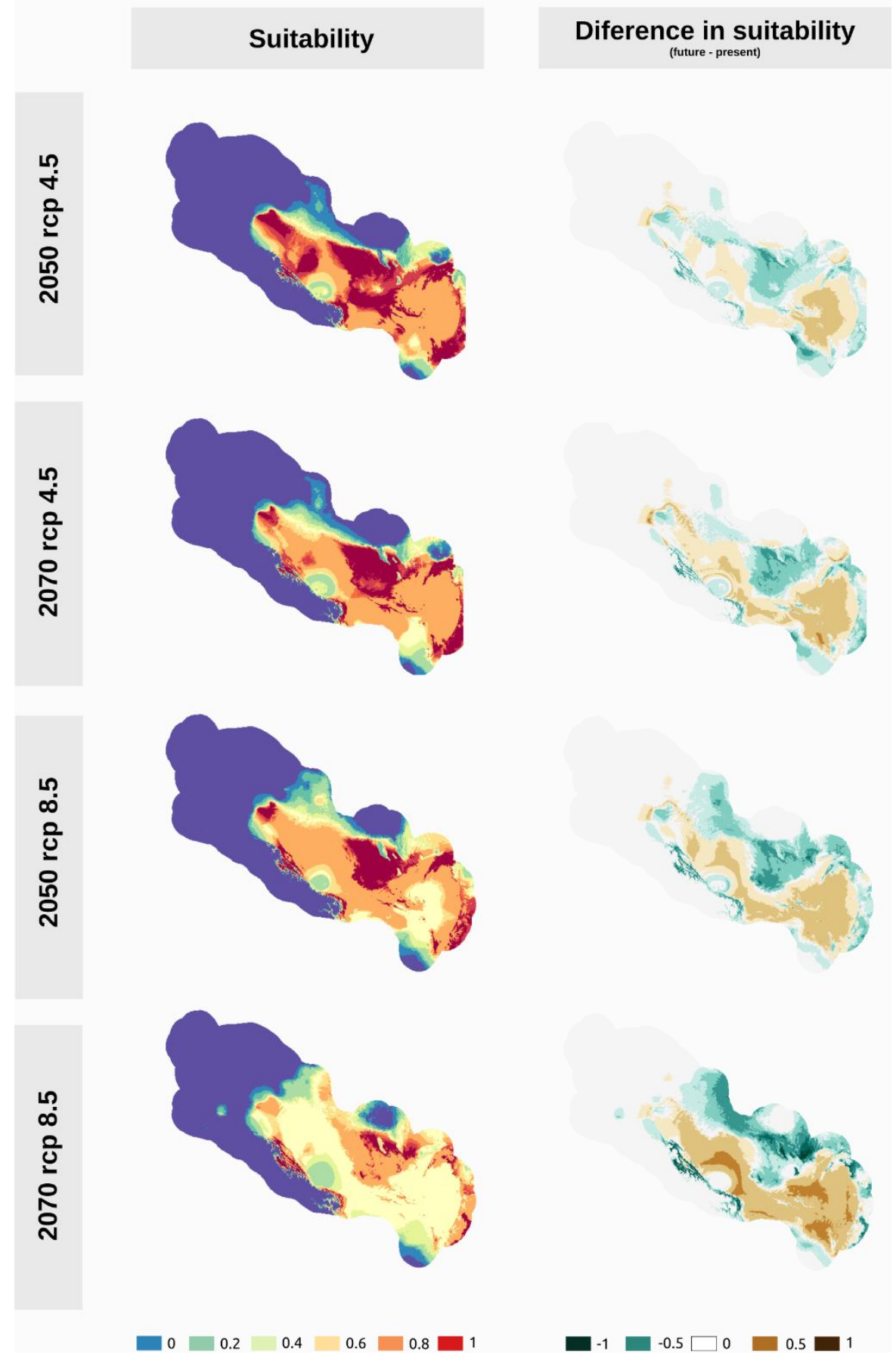




\section{AOGCM MIROC}

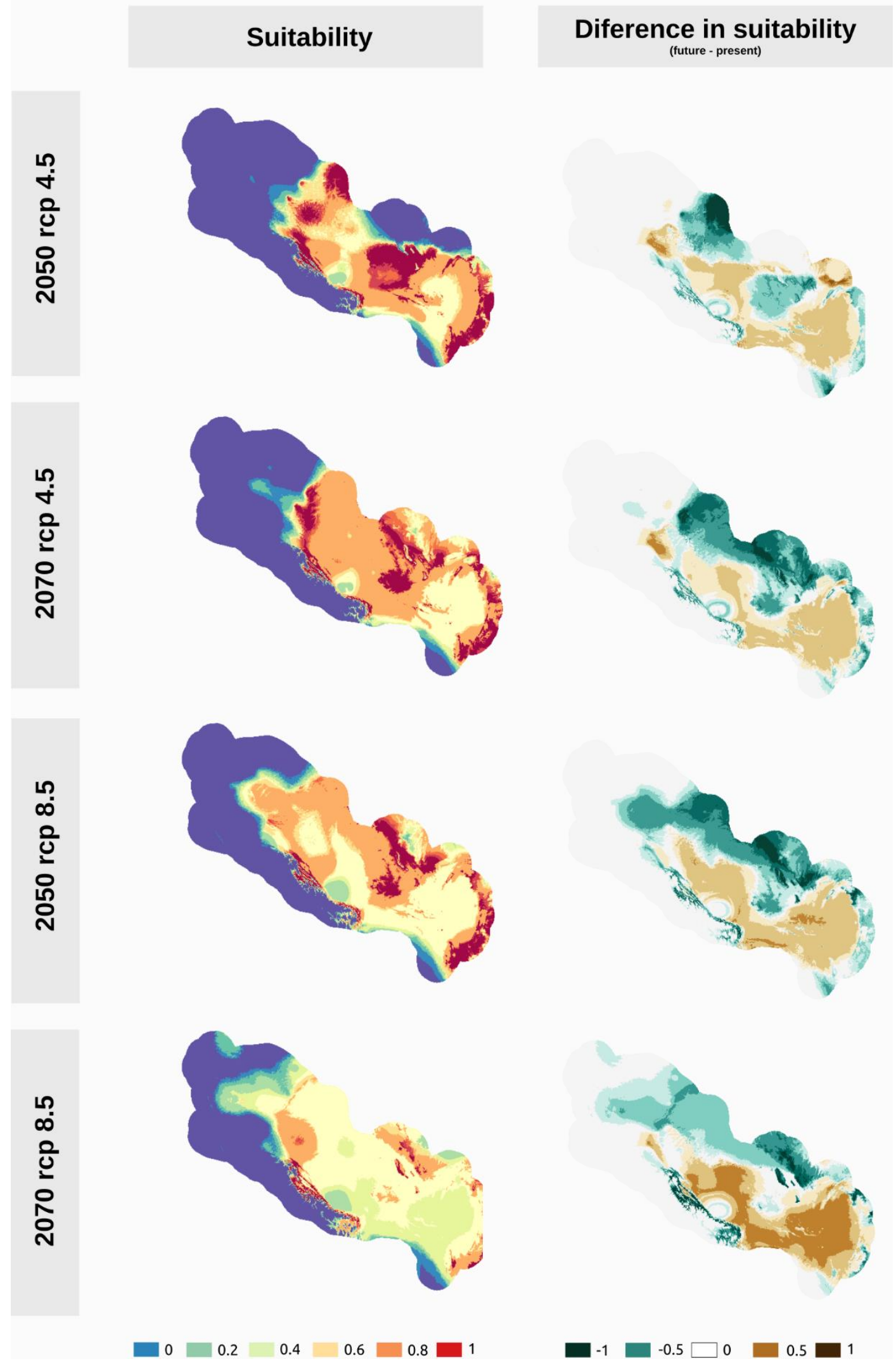




\section{AOGCM MRI}

Suitability
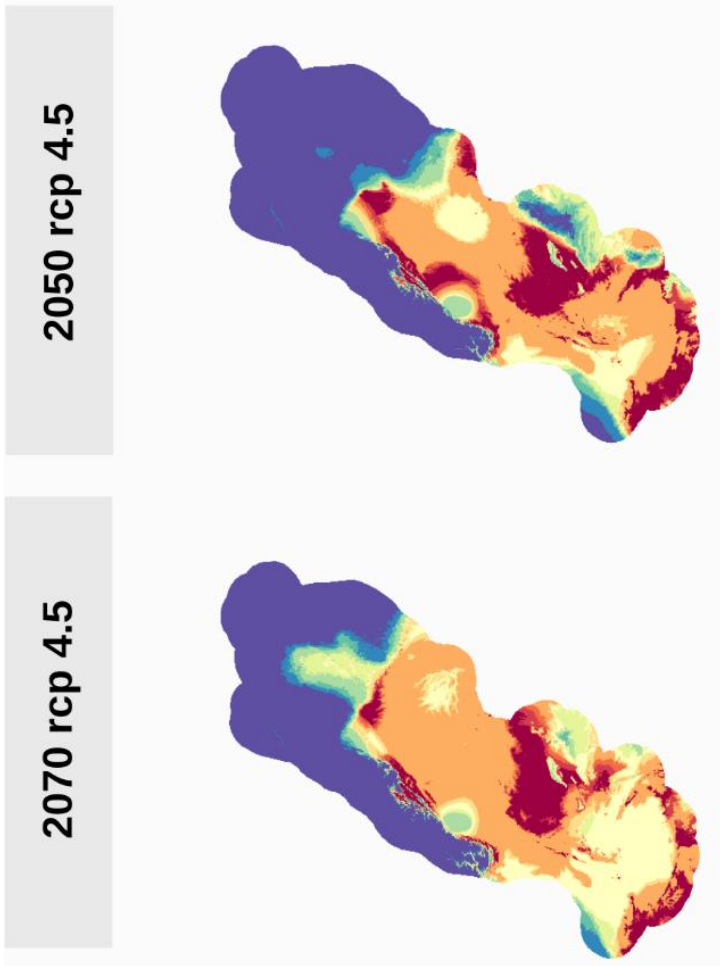

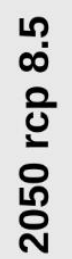

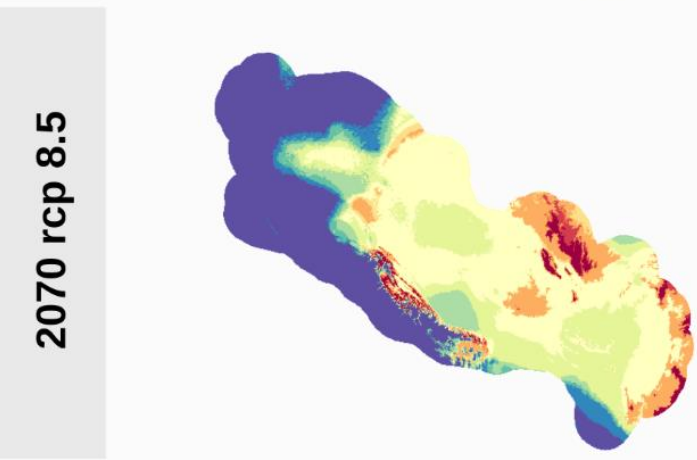

Diference in suitability

(future - present)
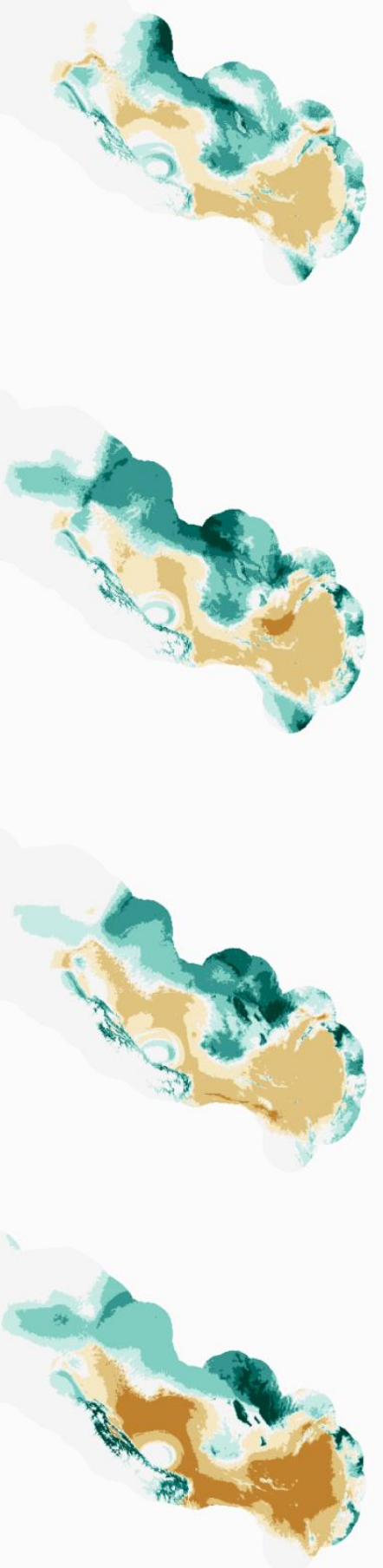

$-1 \square-0.5 \square 0 \quad \square 0.5 \square 1$ 


\section{Appendix 7}

Table A7.7: Results of comparison of different climate scenarios for each dependent variable (elevation, slope, latitude and longitude) performed by post-hoc Dunn test. Variable - Variables compared in post-hot Dunn test (elevation, slope, latitude and longitude); Samples - Present day and future samples (2050 and 2070) compared in the two future contrasting emission scenarios of the Intergovernmental Panel on Climate Change (IPCC), Fifth Assessment Report-Coupled Model Intercomparison Project, Phase 5 (AR-CMIP5) / Representative Concentration Pathway (RCP) 4.5 - lower energy demand, and IPCC AR-CMIP 5 / RCP 8.5 - maximum power requirement, balanced emissions from fossil fuels and non-fossil fuels; post-hoc Dunn test statistic; $P$-adjusted.

\begin{tabular}{|c|c|c|c|}
\hline Variable & Comparison & $\mathrm{Z}$ & $\mathrm{F}$ \\
\hline Elevation & Present - 2050 rcp4.5 & -97.897 & $<0.001$ \\
\hline Elevation & Present - 2070 rcp4.5 & -111.98 & $<0.001$ \\
\hline Elevation & 050 rcp $4.5-2070$ rcp 4.5 & -22.046 & $<0.001$ \\
\hline Elevation & Present - 2050 rcp 8.5 & -111.702 & $<0.001$ \\
\hline Elevation & $2050 \operatorname{rcp} 4.5-2050 \operatorname{rcp} 8.5$ & -25.583 & $<0.001$ \\
\hline Elevation & $2070 \operatorname{rcp} 4.5-2050 \operatorname{rcp} 8.5$ & -4.08 & .001 \\
\hline Elevation & Present - 2070 rcp 8.5 & -93.668 & $<0.001$ \\
\hline Elevation & 2050 rсp $4.5-2070$ rсp 8.5 & -52.084 & 001 \\
\hline Elevation & 2070 rcp $4.5-2070$ rcp 8.5 & -40.426 & $<0.001$ \\
\hline Elevation & $2050 \mathrm{rcp} 8$. & -37.871 & 01 \\
\hline Slope & Present - 2050 rcp 4.5 & -84.449 & $<0.001$ \\
\hline Slope & Present - & -93.561 & 001 \\
\hline Slope & $2050 \operatorname{rcp} 4$ & & 01 \\
\hline Slope & Present - & -93.6 & $<0.001$ \\
\hline Slope & $2050 \mathrm{rcp} 4.5-2$ & -19.669 & $<0.001$ \\
\hline Slope & 2070 rcp $4.5-2050$ rcp8.5 & -3.607 & 0.003 \\
\hline Slope & $2070 \mathrm{rcp} 8.5$ & -65.895 & $<0.001$ \\
\hline Slope & 2050 rcp $4.5-20$ & -31.141 & $<0.001$ \\
\hline Slope & $2070 \operatorname{rcp} 4$ & -22.768 & $<0.001$ \\
\hline Slope & 2050 rсp $8.5-2070$ rсp 8.5 & -20.674 & $<0.001$ \\
\hline Latitude & Present - & -22.443 & $<0.001$ \\
\hline Latitude & Present - 2070 & -23.132 & $<0.001$ \\
\hline Latitude & 2050 rсp $4.5-2070$ rсp 4.5 & -2.725 & 0.064 \\
\hline Latitude & Present - $2050 \mathrm{r}$ & -20.711 & $<0.001$ \\
\hline Latitude & $2050 \operatorname{rcp} 4.5-2050 \operatorname{rcp} 8.5$ & -1.343 & 1 \\
\hline Latitude & 2070 rcp $4.5-2050$ rcp 8.5 & 1.192 & 1 \\
\hline Latitude & Present - 2070 rcp 8.5 & -10.259 & $<0.001$ \\
\hline Latitude & 2050 rсp $4.5-2070$ rсp 8.5 & -0.944 & 1 \\
\hline Lati & $2070 \operatorname{rcp} 4$ & 0.391 & 1 \\
\hline Latitude & 2050 rсp $8.5-2070$ rсp 8.5 & -0.249 & 1 \\
\hline
\end{tabular}




$\begin{array}{lccc}\text { Longitude } & \text { Present }-2050 \text { rcp 4.5 } & 4.122 & <0.001 \\ \text { Longitude } & \text { Present }-2070 \text { rcp 4.5 } & -8.497 & <0.001 \\ \text { Longitude } & \text { 2050 rcp 4.5 - 2070 rcp 4.5 } & -11.188 & <0.001 \\ \text { Longitude } & \text { Present - 2050 rcp 8.5 } & -18.589 & <0.001 \\ \text { Longitude } & \text { 2050 rcp 4.5 - 2050 rcp 8.5 } & -20.434 & <0.001 \\ \text { Longitude } & \text { 2070 rcp 4.5 - 2050 rcp 8.5 } & -9.018 & <0.001 \\ \text { Longitude } & \text { Present - 2070 rcp 8.5 } & -5.784 & <0.001 \\ \text { Longitude } & \text { 2050 rcp 4.5 - 2070 rcp 8.5 } & -7.345 & <0.001 \\ \text { Longitude } & \text { 2070 rcp 4.5- 2070 rcp 8.5 } & -1.795 & 0.727 \\ \text { Longitude } & \text { 2050 rcp 8.5 - 2070 rcp 8.5 } & 3.038 & 0.024\end{array}$




\section{Appendix 8}

Fig.A8.8: Difference between current and future of the four bioclimatic variables used in niche modeling. These values were extracted from the raster used in this study. (RCP: Representative Concentration Pathway)

\section{Temperature Seasonality Difference from the present $\left({ }^{\circ} \mathrm{C}\right)$}

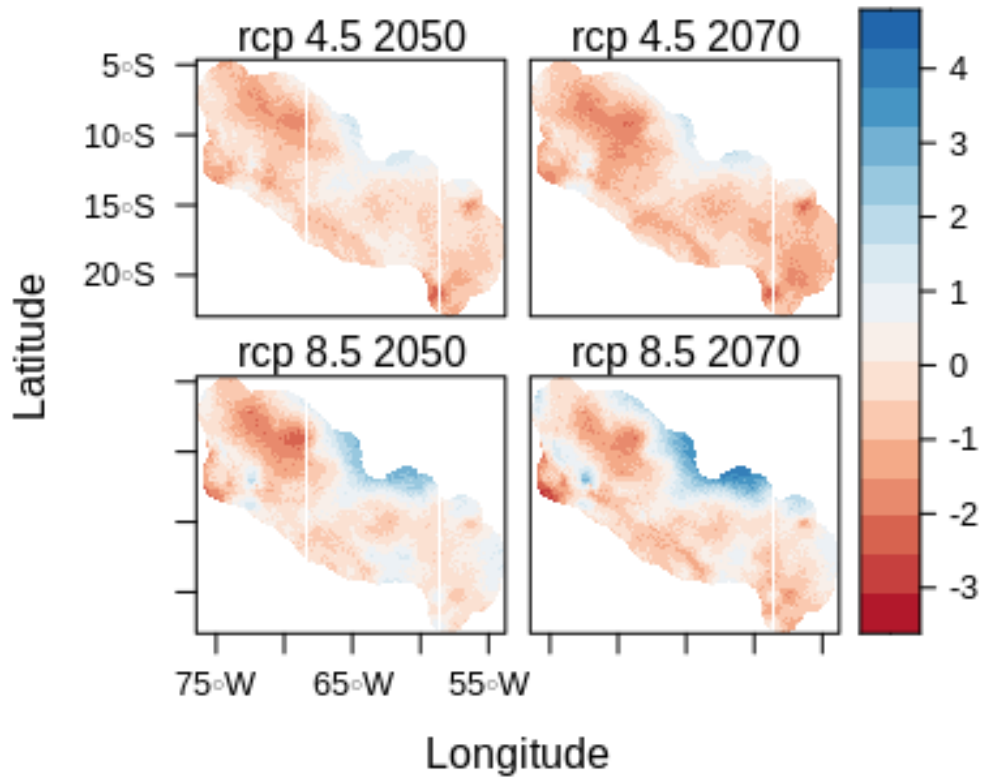

Mean Temperature of Wettest Quarter Difference from the present $\left({ }^{\circ} \mathrm{C}\right)$

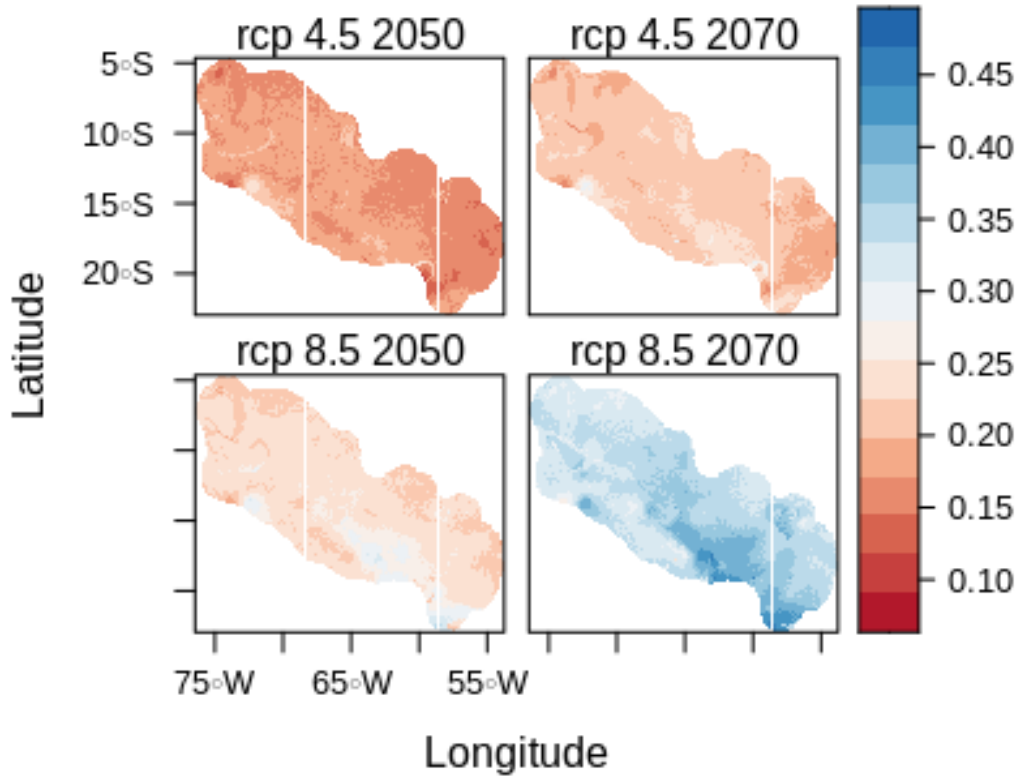


Precipitation of Driest Quarter Difference from the present $(\mathrm{mm})$

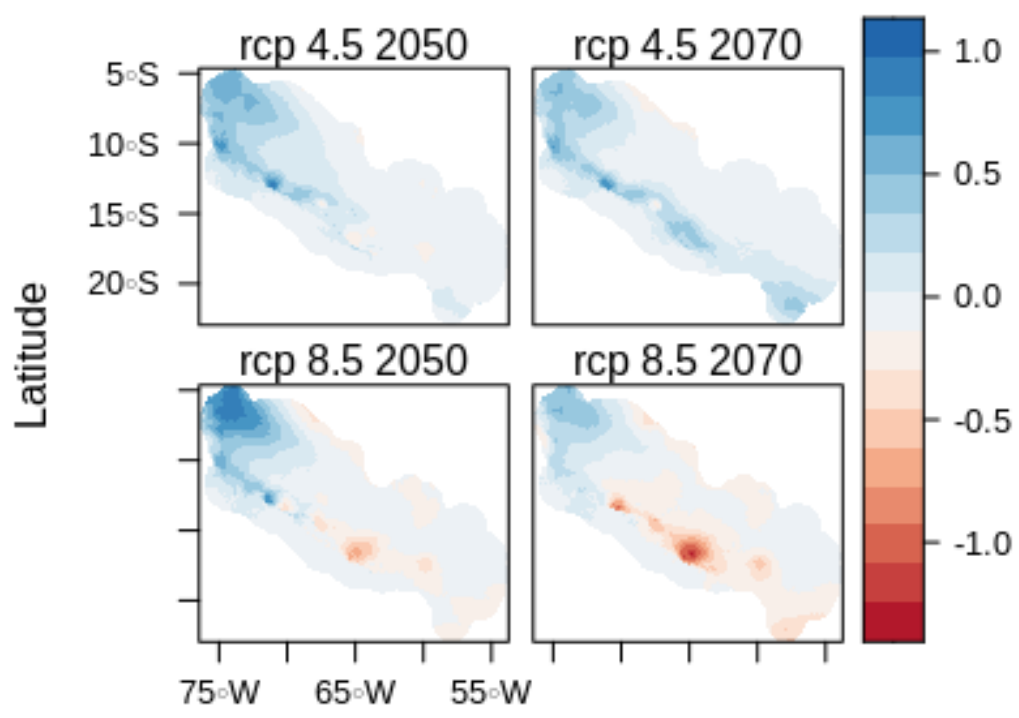

Precipitation of Wettest Quarter Difference from the present $(\mathrm{mm})$

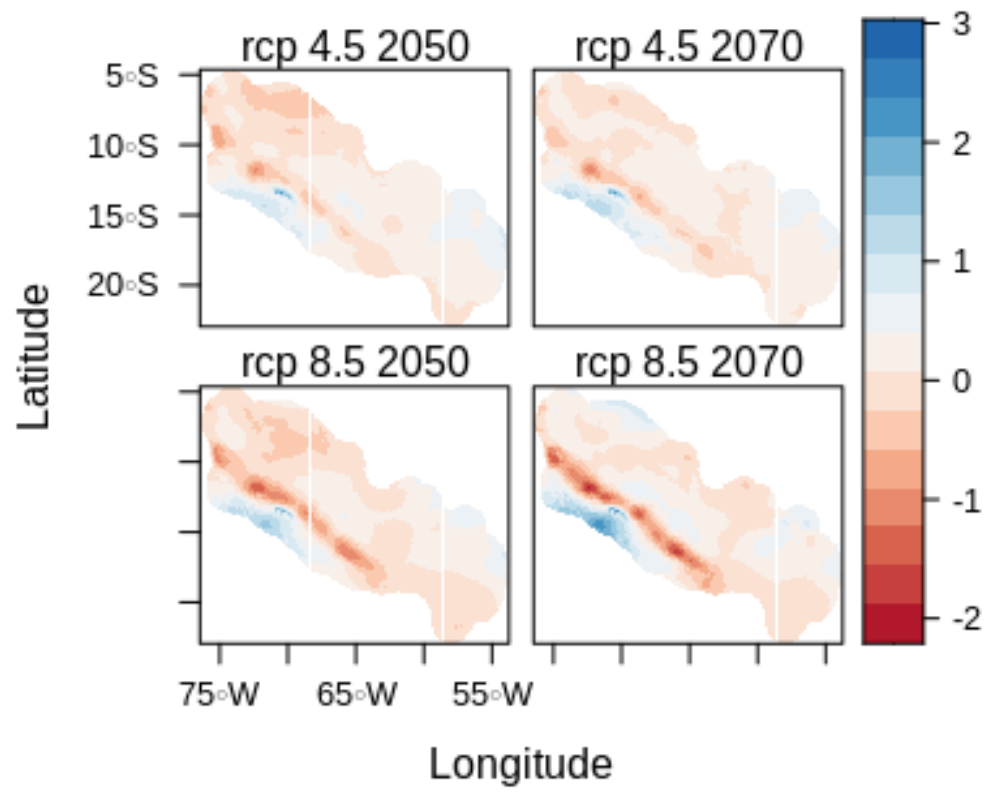




\section{AOGCM MIROC}

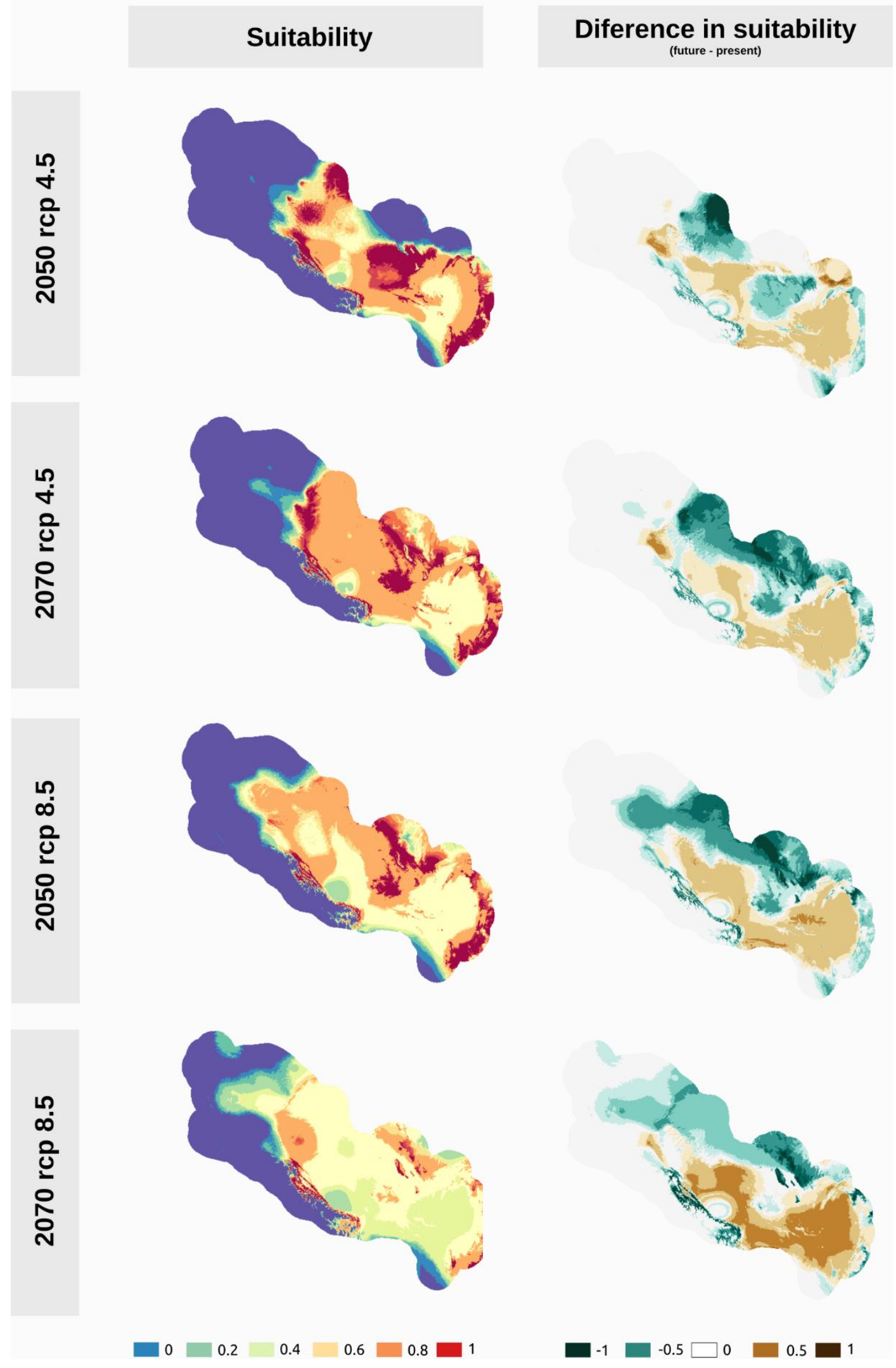




\section{AOGCM MRI}

Suitability
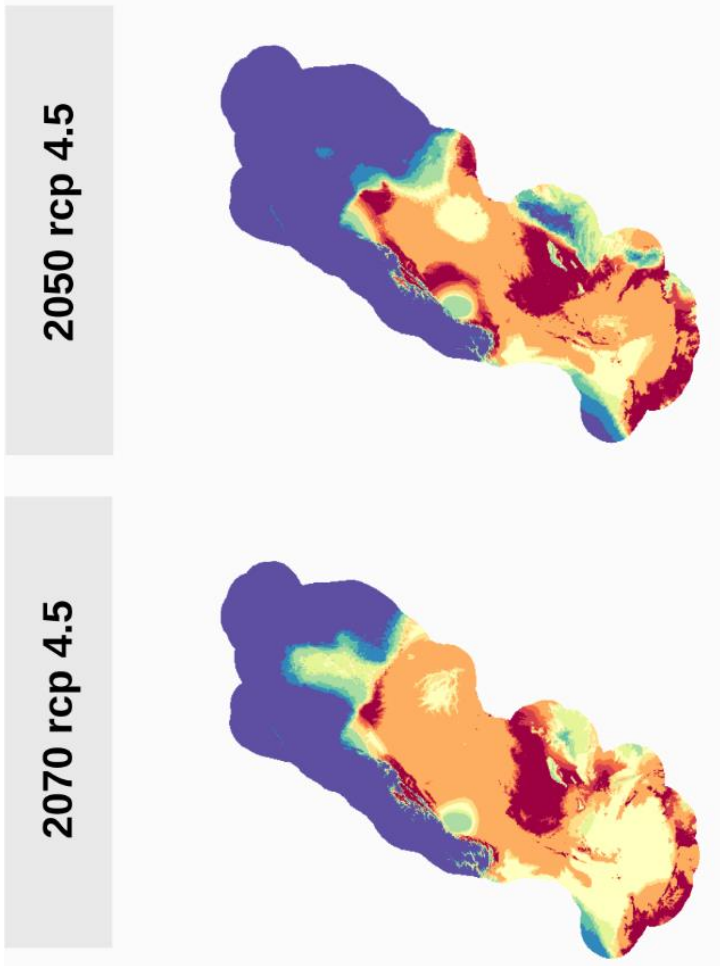

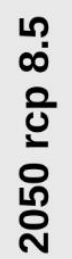

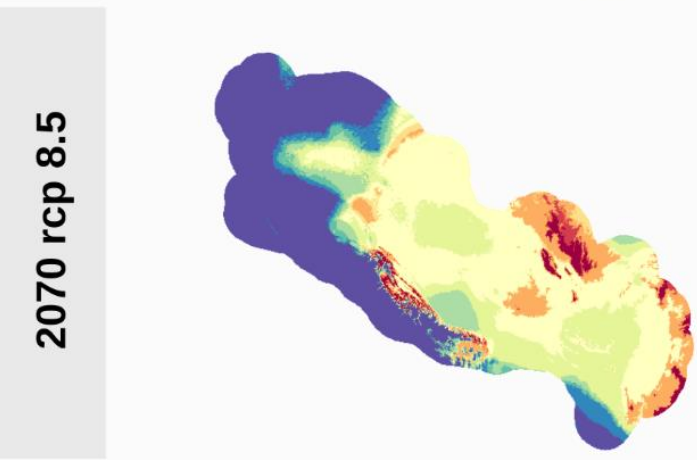

Diference in suitability

(future - present)
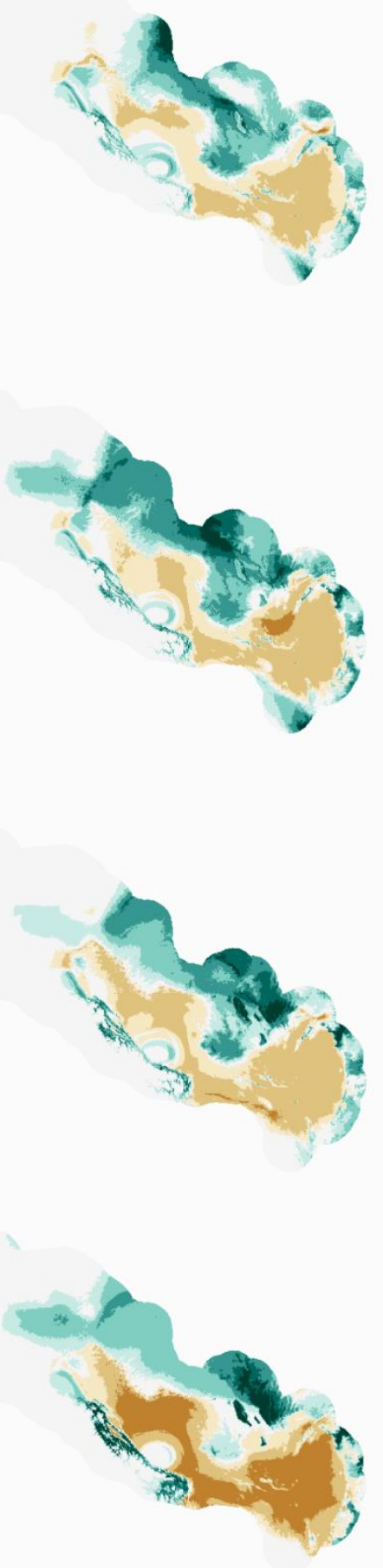

$-1 \square-0.5 \square 0 \quad \square 0.5 \square 1$ 